\title{
Potential climate forcing of land use and land cover change
}

\author{
D. S. Ward ${ }^{1}$, N. M. Mahowald ${ }^{1}$, and S. Kloster ${ }^{2}$ \\ ${ }^{1}$ Earth and Atmospheric Science, Cornell University, Ithaca, New York, USA \\ ${ }^{2}$ Land in the Earth System, Max Planck Institute for Meteorology, Hamburg, Germany
}

Correspondence to: D. S. Ward (dsw25@cornell.edu)

Received: 13 April 2014 - Published in Atmos. Chem. Phys. Discuss.: 14 May 2014

Revised: 16 October 2014 - Accepted: 5 November 2014 - Published: 3 December 2014

Abstract. Pressure on land resources is expected to increase as global population continues to climb and the world becomes more affluent, swelling the demand for food. Changing climate may exert additional pressures on natural lands as present-day productive regions may shift, or soil quality may degrade, and the recent rise in demand for biofuels increases competition with edible crops for arable land. Given these projected trends there is a need to understand the global climate impacts of land use and land cover change (LULCC). Here we quantify the climate impacts of global LULCC in terms of modifications to the balance between incoming and outgoing radiation at the top of the atmosphere (radiative forcing, RF) that are caused by changes in long-lived and short-lived greenhouse gas concentrations, aerosol effects, and land surface albedo. We attribute historical changes in terrestrial carbon storage, global fire emissions, secondary organic aerosol emissions, and surface albedo to LULCC using simulations with the Community Land Model version 3.5. These LULCC emissions are combined with estimates of agricultural emissions of important trace gases and mineral dust in two sets of Community Atmosphere Model simulations to calculate the RF of changes in atmospheric chemistry and aerosol concentrations attributed to LULCC. With all forcing agents considered together, we show that $40 \%$ $( \pm 16 \%)$ of the present-day anthropogenic RF can be attributed to LULCC. Changes in the emission of non- $\mathrm{CO}_{2}$ greenhouse gases and aerosols from LULCC enhance the total LULCC RF by a factor of 2 to 3 with respect to the LULCC RF from $\mathrm{CO}_{2}$ alone. This enhancement factor also applies to projected LULCC RF, which we compute for four future scenarios associated with the Representative Concentration Pathways. We attribute total RFs between 0.9 and $1.9 \mathrm{~W} \mathrm{~m}^{-2}$ to LULCC for the year 2100 (relative to a preindustrial state). To place an upper bound on the potential of
LULCC to alter the global radiation budget, we include a fifth scenario in which all arable land is cultivated by 2100 . This theoretical extreme case leads to a LULCC RF of $3.9 \mathrm{~W} \mathrm{~m}^{-2}$ $\left( \pm 0.9 \mathrm{~W} \mathrm{~m}^{-2}\right)$, suggesting that not only energy policy but also land policy is necessary to minimize future increases in $\mathrm{RF}$ and associated climate changes.

\section{Introduction}

More than half of the Earth's land surface has been affected by land use and land cover change (LULCC) activities over the last 300 years, largely from the expansion of agriculture (Hurtt et al., 2011), leading to numerous climate impacts (Foley et al., 2005). Conversion of land from natural vegetation to agriculture or pasturage releases carbon from vegetation and soils into the atmosphere (Houghton et al., 1983), often quickly through fires, which emit carbon dioxide $\left(\mathrm{CO}_{2}\right)$, methane $\left(\mathrm{CH}_{4}\right)$, ozone $\left(\mathrm{O}_{3}\right)$-producing compounds, and aerosols (Randerson et al., 2006). Deforested areas have a diminished capacity to act as a $\mathrm{CO}_{2}$ sink as atmospheric $\mathrm{CO}_{2}$ concentrations increase (Arora and Boer, 2010; Strassmann et al., 2008). Furthermore, agriculture and pasturage emits $\mathrm{CH}_{4}$ and nitrous oxide $\left(\mathrm{N}_{2} \mathrm{O}\right)$, accelerates soil carbon loss (Lal, 2004), and changes aerosol emissions (Foley et al., 2011). For instance, land management can enhance mineral dust aerosol emission by modifying surface sediments and soil moisture (Ginoux et al., 2012), but reduces fire aerosol emissions (Kloster et al., 2012) and emissions of low-volatility products of oxidized biogenic organic compounds that condense to form secondary organic aerosols (SOA; Heald et al., 2008). Changes in the abundance of these atmospheric constituents generate forcings onto the climate 
system (Fig. 1), quantified in this study as radiative forcings (RFs).

The global RF and associated climate response attributable to LULCC are often portrayed as a balance between cooling biogeophysical effects (changes in surface energy and water balance) and the warming biogeochemical effect of increases in atmospheric $\mathrm{CO}_{2}$ (e.g., Claussen et al., 2001; Brovkin et al., 2004; Foley et al., 2005; Bala et al., 2007; Cherubini et al., 2012). Claussen et al. (2001) found that the cooling from biogeophysical effects of land cover change dominated over the warming from associated $\mathrm{CO}_{2}$ emissions in high-latitude regions, where the land may be snow covered for part of the year, whereas tropical LULCC leads to a warming due to a weaker albedo forcing. This regional contrast in the dominant forcing from deforestation also applies to natural forest disturbances (O'Halloran et al., 2011). On a global scale, model estimates have shown both canceling climate responses to historical land cover change biogeophysical effects and $\mathrm{CO}_{2}$ emissions (Brovkin et al., 2004; Sitch et al., 2005) and a net warming $\left(0.15^{\circ} \mathrm{C}\right)$ from the same effects (Matthews et al., 2004).

Additional LULCC forcings are often grouped together with fossil fuel burning and other activities for assessment of the total anthropogenic RF (e.g., Forster et al., 2007; Myhre et al., 2013). Nevertheless, there is some recognition of the importance of evaluating emissions of non- $\mathrm{CO}_{2}$ greenhouse gases attributable to LULCC separately from fossil fuel emissions for targeting emission reduction policies (Tubiello et al., 2013). Less attention is given to forcings from short-lived atmospheric species that are affected by LULCC. Foley et al. (2005) acknowledge that changes in the concentrations of short-lived species, aerosols and $\mathrm{O}_{3}$, attributable to LULCC are important for air quality assessment but do not estimate the impacts of these species on climate. Unger et al. (2010) partition sources of global, anthropogenic RF into economic sectors, including agriculture. They consider non- $\mathrm{CO}_{2}$ greenhouse gas and aerosol forcing agents but only for present-day land use emissions and they do not include land cover change. The full contribution of LULCC to global RF compared to the contribution from other anthropogenic activities remains unquantified.

Here we compute the $\mathrm{CO}_{2}$ and albedo RF attributable to global LULCC and compare to previous estimates of these values, but we also compute the forcings from non- $\mathrm{CO}_{2}$ greenhouse gases $\left(\mathrm{CH}_{4}, \mathrm{~N}_{2} \mathrm{O}, \mathrm{O}_{3}\right)$, as well as aerosol effects (direct, indirect, deposition on snow and ice surfaces). Individual forcings are computed from the results of terrestrial model simulations forced with historical land cover changes and wood harvesting, and projected land cover changes from five future scenarios. Because the land model used here includes a carbon model, fire module, and emissions of volatile organic compounds, we can uniquely account for the complicated interplay between land use and fire (e.g., Marlon et al., 2008; Kloster et al., 2010; Ward et al., 2012). Four of the future scenarios of land cover change correspond

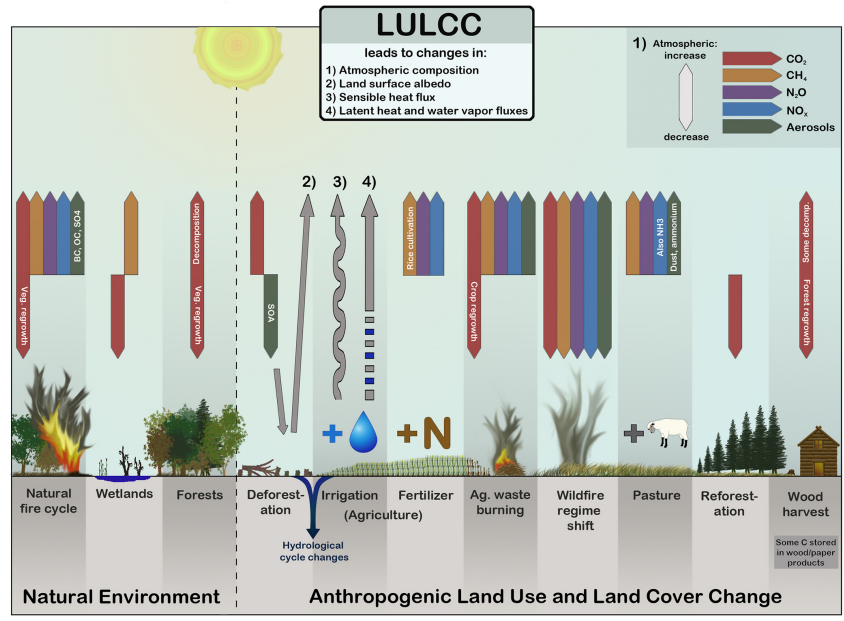

Figure 1. A schematic illustration of the climate impacts of land use and land cover change. See Fig. 2 for a representation of the processes and emissions included in this study.

to the four Representative Concentration Pathways (RCPs) that were developed for the Climate Model Intercomparison Project in preparation for the IPCC 5th assessment report (AR5) (Lawrence et al., 2012; Hurtt et al., 2011; van Vuuren et al., 2011). The low-emissions scenario, RCP2.6, includes widespread proliferation of bioenergy crops (van Vuuren et al., 2007), while RCP4.5 is characterized by global reforestation as a result of carbon credit trading and emission penalties (Wise et al., 2009). The higher emissions scenarios include expansion of crop area at the expense of existing grasslands (RCP6.0; Fujino et al., 2006) or forests (RCP8.5; Riahi et al., 2007; Hurtt et al., 2011). We introduce a fifth, more extreme scenario in which all arable and pasturable land is converted to agricultural land, either for crops or pasture, by the year 2100. This scenario, hereafter referred to as the theoretical extreme case (TEC), was not developed within an integrated modeling framework, and therefore its likelihood of occurrence given economical and additional environmental constraints is difficult to judge. Instead, this scenario gives a theoretical upper bound on LULCC impacts over this century. The range in outcomes for the RF attributable to LULCC based on these five projections strengthens our understanding of the role that LULCC decision making will play in future climate.

\section{Overview of methods}

Our approach for computing the RFs begins with estimating emissions of trace gases and aerosols from a diverse set of LULCC activities, many of which are illustrated schematically in Fig. 1. For several forcing agents, including $\mathrm{CO}_{2}$, we isolate the LULCC emissions by comparing global transient simulations of the terrestrial biosphere including LULCC to simulations without LULCC that are otherwise identical, and 
attribute the difference in emissions between these simulations to LULCC. This general approach, attributing the differences between the LULCC and no-LULCC environment to the impacts of LULCC, also applies to our calculations of RFs. Our methods for computing these and other emissions from LULCC activities, as well as the calculations of changes in atmospheric constituent concentrations and RFs are summarized in this section and schematically in Fig. 2.

\subsection{LULCC activities}

We model the following LULCC activities with a global terrestrial model: wood harvesting, land cover change, and changes in fire activity, including deforestation fires. Changes in the terrestrial model carbon cycle driven by the historical and projected LULCC are used to derive the RF of surface albedo change, as well as emissions of $\mathrm{CO}_{2}, \mathrm{SOA}$, smoke, and mineral dust from LULCC (Fig. 2). We assemble emissions from additional LULCC activities: agricultural waste burning, rice cultivation, fertilizer applications, and livestock pasturage, from available data sets corresponding to the RCP LULCC projections.

Future land cover changes and wood harvesting rate projections have been developed as part of the Coupled Model Intercomparison Project phase 5 (CMIP5) (Taylor et al., 2012) with projections corresponding to each of the four RCP scenarios (Hurtt et al., 2011; van Vuuren et al., 2011). These projections have since been joined to historical reconstructions of land use (Hurtt et al., 2011) and expressed as changes in fractional plant functional types (PFTs) which we use in this study with recently amended wood harvesting rates for RCP6.0 and RCP8.5 (Lawrence et al., 2012). Global forest area decreases in all projections between 2010 and 2100 except for RCP4.5, which projects large reforestation efforts (Fig. A1). The loss in forests is accompanied by increases in global crop area in all scenarios except RCP4.5, in which crop area decreases to a level not seen since the 1930s (Fig. A1). Development of PFT changes for the TEC is described in Appendix A.

While we consider this list of activities to be highly inclusive, several LULCC activities and processes are not included in this study, either because they are difficult to properly model or represent as a forcing, or because of a poor level of current understanding of the process. We exclude the impacts of anthropogenic water use, mainly irrigation, on global water vapor concentrations and the associated RF (Boucher et al., 2004). Changes in water use and land use have numerous other implications for the hydrological cycle, including impacts on evapotranspiration, runoff, and wetland extent (Sterling et al., 2013). Related to these effects, the impact of land surface albedo changes may be further moderated by changes in cloudiness (Lawrence and Chase, 2010), which we did not consider in this analysis. Also, emissions of $\mathrm{CH}_{4}$ are tied to the global extent of wetlands, which have likely changed since preindustrial times (Lehner and Doll,

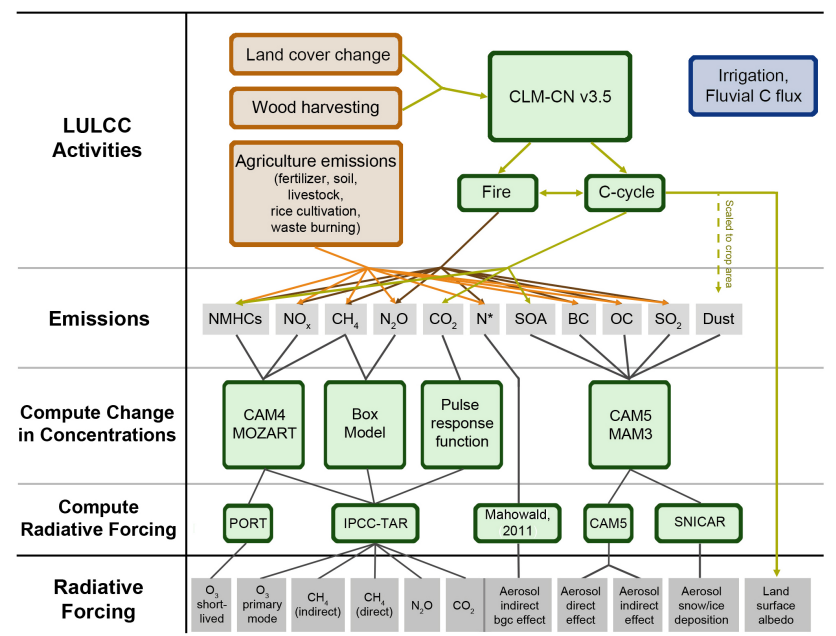

Figure 2. A flow chart summarizing the methodology used in this study to compute the RF of the various forcing agents of LULCC. The colors of the boxes indicate processes that are independent of this study (orange); processes and computational steps that were completed as part of this study (green); and processes that were not included in this study, but are likely important for climate (blue). Acronyms are defined as follows: CLM-CN (Community Land Model with Carbon/Nitrogen cycles) (Oleson et al., 2008; Stöckli et al., 2008), CAM (Community Atmosphere Model) (Gent et al., 2011), MOZART (Model for Ozone and Related Chemical Tracers) (Emmons et al., 2010), PORT (Parallel Offline Radiative Transfer) (Conley et al., 2013), TAR (Third Assessment Report) (Ramaswamy et al., 2001), and SNICAR (Snow Ice and Radiative Aerosol Model) (Flanner and Zender, 2006). *: total nitrogen $(\mathrm{N})$ includes contributions from $\mathrm{NH}_{3}, \mathrm{~N}_{2} \mathrm{O}$, and $\mathrm{NO}_{\mathrm{x}}$ emissions.

2004), but the scale and distribution of the change is not yet known well enough to be included in our model setup. We assume that natural $\mathrm{CH}_{4}$ emissions remain unchanged from 1850 through 2100 for all scenarios. Finally, there is a source of $\mathrm{CO}_{2}$ from deforestation and forest degradation in tropical peat swamp forests that has only recently been widely recognized (Hergoualc'h and Verchot, 2011), although it is thought that contributions from this source to current global $\mathrm{CO}_{2}$ concentrations are small (Frolking et al., 2011).

\subsection{LULCC emissions (computed from CLM)}

Changes in terrestrial carbon storage, fire activity, and biogenic trace gas emissions due to dynamic land cover are simulated using version 3.5 of the Community Land Model (CLM) (Oleson et al., 2008; Stöckli et al., 2008) with active carbon and nitrogen cycles (CN) (Thornton et al., 2009) coupled to a process-based fire model (Kloster et al., 2010). This configuration of CLM simulates the complicated interplay between land use, land use change, fires, land carbon uptake and loss, and emissions of volatile organic compounds (Thornton et al., 2009; Kloster et al., 2010; Guenther et al., 2006). To isolate the impacts of LULCC we perform separate 
simulations for each of the LULCC dynamic PFT scenarios and compare it to an identical simulation with no PFT changes. All CLM simulations use $1.9^{\circ}$ latitude by $2.5^{\circ}$ longitude spatial resolution and a 30 min time step.

Spinup of CLM is carried out with year 1850 land cover, which includes some anthropogenic changes. Simulations of historical LULCC run from year 1850 to 2005 and future simulations from year 2006 to 2100 . We compute forcings in the year 2010 assuming historical LULCC was extended to 2010 with RCP2.6 land cover changes. We follow the methods of Kloster et al. (2012) for historical and future atmospheric forcing, including meteorology, $\mathrm{CO}_{2}$ concentrations, and $\mathrm{N}$ deposition. Twelve future CLM simulations are run, two for each future LULCC scenario (RCP2.6, RCP4.5, RCP6.0, RCP8.5, theoretical extreme case, and No-LULCC) forced from the atmosphere with temperature, precipitation, wind, specific humidity, air pressure, and solar radiation data from the results of two fully coupled CMIP3 simulations. The two sets of atmospheric forcing were selected for their divergent predictions of future temperature and precipitation (Kloster et al., 2012).

\subsubsection{Fires}

Fire area burned in CLM is controlled by available biomass, fuel moisture, and ignition events, all expressed as probabilities, and adjusted by surface wind speeds (Kloster et al., 2010). Fire emissions from the area burned are contingent upon the available biomass and are partly determined by PFT-dependent combustion completeness. In addition to wildfires, deforestation fires occur in the model and are represented as an immediate release of a portion of the carbon lost during deforestation. In our analysis, deforestation fires do not impact the overall $\mathrm{CO}_{2} \mathrm{RF}$ but do speed up the timing of the release of carbon that would otherwise occur by decomposition. Deforestation fires do, however, contribute small amounts of $\mathrm{CH}_{4}, \mathrm{~N}_{2} \mathrm{O}, \mathrm{O}_{3}$ precursor gases, and aerosols to the atmosphere that would not have been released through decomposition.

We attribute a reduction in global burned area, both historically and in the future, to LULCC in our simulations (for RCP4.5, which includes large-scale reforestation, the reduction is only a few percent). This result matches our current understanding of the impact of LULCC on wildfires (Kloster et al., 2012; Marlon et al., 2008).

Emissions of trace gases and aerosols by wildfires and deforestation fires are derived from the CLM simulations of global fire activity. We use 10-year annual average fire carbon emission output from CLM, corresponding to each analysis year $(1850,2010,2100)$, to reduce the influence of interannual variability in fires. Emission factors are applied to the carbon emissions from fires to determine the contribution of fires to the various chemical species (see Fig. 2), including non-methane hydrocarbons (NMHCs), $\mathrm{CH}_{4}, \mathrm{~N}_{2} \mathrm{O}, \mathrm{NH}_{3}$, BC, OC, and $\mathrm{SO}_{2}$ (Kloster et al., 2010; Ward et al., 2012).
The LULCC contribution to global fire emissions of BC and OC is negative in the year $2010(-13 \%)$, in the year 2100 for all scenarios except for RCP4.5, compared to the no-LULCC CLM realization (Table 1).

\subsubsection{Dust emissions}

Agricultural activities have been linked to increased wind erosion of soils and greater dust emission in semiarid regions (Ginoux et al., 2012). To address the impact of LULCC on dust emissions we introduce a modified soil erodibility data set for each scenario into simulations with the Community Atmosphere Model (CAM) version 5 (Liu et al., 2011). The model protocol for these simulations is identical to that used to compute the aerosol forcings (see Appendix B5). For each model grid box, a new soil erodibility value is set equal to the sum of the original soil erodibility and the fraction of the grid box that is cultivated land. We then introduce a parameter that weights the cultivated fraction in the soil erodibility computation such that the fraction of the dust flux resulting from cultivation in the year 2000 for eight regions (N. America, S. America, N. Africa, S. Africa, W. Asia, C. Asia, E. Asia, and Australia) is comparable to recently reported, satellitederived values for each region (Ginoux et al., 2012). The weighting parameter for cultivated land was tuned with three iterations of 4-year global atmospheric model simulations (again using the model setup described in Appendix B5), comparing the results for the tuned and un-tuned soil erodibility to the Ginoux et al. (2012) estimates for each region after each iteration. From this tuning we estimate reasonable weighting parameters for the cultivated fraction of land in each of the eight regions. The weighting parameters are applied to the time series of historical and projected crop area to create time series of soil erodibility that are modified by cultivation.

Ginoux et al. (2012) estimate that $25 \%$ of present-day, global dust emissions are caused by anthropogenic activities. We attribute about $20 \%$ of global dust emissions to historical LULCC (Table 1). Once these relationships between land use and dust are developed in the current climate, the natural dust source, along with changes in vegetation and climate are allowed to interact with the prognostic dust scheme to predict changes in dust concentrations (Mahowald et al., 2006; Albani et al., 2014). The extreme expansion of crop and pasture area in the TEC leads to more than a tripling of global dust emissions, from natural and human-impacted sources, by the year 2100 using this methodology (Table 1).

\subsubsection{SOA emissions}

Biogenic emissions of isoprene, monoterpenes, carbon monoxide (CO), and methanol depend on leaf area index (LAI) and therefore also on LULCC. We compute biogenic trace gas emissions using an offline version of the Model of Emissions of Gases and Aerosols from Nature (MEGAN) 
Table 1. Emissions of important aerosol and trace gases attributed to LULCC activities for year 2010 and year 2100 for the listed future scenarios (theoretical extreme case is abbreviated to TEC). Values are given in $\mathrm{Tg}$ (species) $\mathrm{yr}^{-1}$ except where noted otherwise. Values in parentheses are the percentage change in global emissions attributed to LULCC for the year and scenario listed. Biogenic SOA precursors are considered the sum emissions of biogenic $\mathrm{CO}$, isoprene, monoterpenes, and methanol.

\begin{tabular}{lrrrr}
\hline & & & $\begin{array}{r}\text { Biogenic SOA } \\
\text { precursors }\end{array}$ & $\begin{array}{r}\text { Fire } \\
\mathrm{N}_{2} \mathrm{O}\end{array}$ \\
& {$\left[\mathrm{Tg} \mathrm{C}^{-1}\left(\mathrm{~N}_{2} \mathrm{O}\right) \mathrm{yr}^{-1}\right]$} & Dust & $(\mathrm{BC}+\mathrm{OC})$ \\
\hline 2010 & 4.3 & $+619(18)$ & $+7(1)$ & $-2.2(13)$ \\
RCP2.6 & 5.4 & $+1003(28)$ & $-141(16)$ & $-6.0(25)$ \\
RCP4.5 & 2.9 & $+806(23)$ & $-54(6)$ & $+1.8(8)$ \\
RCP6.0 & 3.8 & $+1008(28)$ & $-105(12)$ & $-4.0(17)$ \\
RCP8.5 & 5.3 & $+866(24)$ & $-149(16)$ & $-8.1(34)$ \\
TEC & 11.7 & $+4330(222)$ & $-656(74)$ & $-15.4(65)$ \\
\hline
\end{tabular}

(Guenther et al., 2006) with a forced diurnal cycle for temperature and solar radiation (Ashworth et al., 2010). The monthly average LAI outputs from CLM are used for each scenario to produce the biogenic emissions with LAI scaled globally such that predicted year 2000 isoprene emissions match present-day global estimates from Heald et al. (2008).

Some biogenic NMHCs, notably monoterpenes and isoprene, can undergo gas-to-particle phase transitions in the atmosphere after oxidation (Heald et al., 2008) and contribute to changes in aerosol concentrations. The rate of secondary aerosol production depends on the concentrations of the gas precursors, as well as the oxidation capacity of the troposphere (Shindell et al., 2009). Both criteria are predicted in our atmospheric chemistry model simulations, described in Appendix B2. On a global average, we estimate a negligible LULCC-attributed share of biogenic SOA precursors (mainly isoprene) in the year 2010 and attribute larger reductions to projected changes in land cover for the future RCPs between 6 and $16 \%$ (Table 1), similar to the results of Wu et al. (2012) for isoprene plus monoterpene emissions $(\sim 10 \%$ lower with LULCC) between 2000 and 2100 using the IPCC A1B future emissions scenario.

\subsection{4 $\mathrm{CO}_{2}$ emissions}

The anthropogenic contribution to the concentration of atmospheric $\mathrm{CO}_{2}$, used to compute the RF at years 2010 and 2100 , depends on the history of anthropogenic $\mathrm{CO}_{2}$ emissions up to that point. We estimate yearly LULCC emissions to the atmosphere as being equivalent to the global annual change in terrestrial carbon storage due to LULCC. Therefore, sources as well as changes to sinks of $\mathrm{CO}_{2}$ associated with LULCC are accounted for in the $\mathrm{CO}_{2}$ emissions. This approach is most similar to the "D3" group of studies as defined by Pongratz et al. (2014), in which simulations with and without LULCC are conducted with identical meteorological and atmospheric $\mathrm{CO}_{2}$ forcing.

As noted in previous studies (e.g., Strassmann et al., 2008; Arora and Boer, 2010; Pongratz et al., 2009, 2014), this methodology does not account for the $\mathrm{CO}_{2}$-fertilization feedback in which the $\mathrm{CO}_{2}$ attributed to LULCC leads to greater fertilization of natural and managed vegetation and an enhanced terrestrial carbon sink. Arora and Boer (2010) show that excluding the $\mathrm{CO}_{2}$-fertilization feedback leads to a form of "double-counting" land carbon storage and can cause overestimates of 20th century LULCC net carbon flux by about $50 \%$. A review of the few studies estimating this feedback gives a range for the overestimate of the net carbon flux from LULCC of 25 to $50 \%$ (Pongratz et al., 2014). However, a recent model intercomparison study suggested that including nitrogen $(\mathrm{N})$ limitation dramatically reduces terrestrial carbon pool sensitivity to changes in $\mathrm{CO}_{2}$ concentration (Arora et al., 2013). Land carbon uptake in coupled models using the $\mathrm{CN}$ version of CLM was only $40 \%$ as sensitive to changes in $\mathrm{CO}_{2}$ concentration and surface temperature increases (known as the climate change feedback) compared to the model used by Arora and Boer (2010). Therefore we adjusted the yearly LULCC net carbon flux downward by $20 \%$ to account for the $\mathrm{CO}_{2}$ fertilization feedback and make our calculations of $\mathrm{CO}_{2}$ concentration increases attributed to LULCC more consistent with the "E2" group of studies as defined by Pongratz et al. (2014), including Arora and Boer (2010), Strassmann et al. (2008), and Pongratz et al. (2009).

Other model parameters, including aerosol and biogenic NMHC fluxes, depend on LAI, which would also be impacted by the different $\mathrm{CO}_{2}$ fertilization. However, due to the nonlinearity of the aerosol and ozone response, we do not apply an adjustment to these RFs but note here that the magnitude of the year 2010 aerosol, $\mathrm{O}_{3}$, and indirect $\mathrm{CH}_{4}$ RFs may be small overestimates.

Our simulated net carbon flux from LULCC does not include the impacts of cultivation on soil carbon amounts. Model estimates of carbon emissions from soils that have been disrupted by land use are poorly constrained (Houghton, 2010) and introduce major uncertainty into estimates of the net LULCC carbon flux (House et al., 2002). In a review of field studies, Guo and Gifford (2002) conclude 
that soil carbon is increased following most conversions of natural land to pasture, and decreased following conversions to cropland. Lal (2004) estimates that cultivation has caused the loss of $78 \pm 12 \mathrm{PgC}$ from soils since 1850 . Modeling studies suggest that LULCC can contribute a net loss of soil carbon globally, from $\sim 13 \%$ of total LULCC carbon emitted (Strassmann et al., 2008) to $~ 37 \%$ (Shevliakova et al., 2009), or a net gain as in Arora and Boer (2010). Recently, Levis et al. (2014) implemented a cultivation parameterization that includes impacts on soil carbon and found an additional global flux of $0.4 \mathrm{PgC}_{\mathrm{gr}}{ }^{-1}$ from soils due to crop management in recent decades.

\subsection{LULCC emissions (not computed from CLM)}

This section describes the sources and accompanying computations for LULCC emissions of all relevant trace gas and aerosol species not derived from the CLM simulations in this study (Fig. 2). For non-LULCC-related emissions (such as those from fossil fuel burning) we use the emission inventories from the Atmospheric Chemistry and Climate Model Intercomparison Project (ACCMIP) (Lamarque et al., 2010) for historical time periods, with future emissions from RCP4.5 (Wise et al., 2009). These data sets include emissions of nonmethane hydrocarbons (NMHCs), $\mathrm{NO}, \mathrm{NH}_{3}, \mathrm{SO}_{2}$, and organic carbon (OC) and black carbon (BC) aerosols.

\subsubsection{Agricultural emissions}

Agricultural emissions of important trace gas species, such as $\mathrm{NH}_{3}$ and $\mathrm{N}_{2} \mathrm{O}$, are not simulated by CLM. Therefore, additional emissions from LULCC activities associated with agriculture were taken from the integrated assessment model emissions for the different RCPs (e.g., van Vuuren et al., 2011). These activities are fertilizer application, soil modification, livestock pasturage, rice cultivation, and agricultural waste burning, and we include global emissions of NMHCs, $\mathrm{NO}_{\mathrm{x}}, \mathrm{CH}_{4}, \mathrm{NH}_{3}, \mathrm{BC}, \mathrm{OC}$, and $\mathrm{SO}_{2}$ from LULCC sources. $\mathrm{N}_{2} \mathrm{O}$ emissions are not reported by sector for the RCPs and we compute these separately (Sect. 2.3.2). The four integrated assessment models (IAMs) associated with the RCPs for the fifth IPCC assessment report simulate the expansion and contraction of agriculture driven by the demand for food and projected land use policies, such as carbon credits for reforestation or support of expanded biofuel crops (van $\mathrm{Vu}$ uren et al., 2011). The area under cultivation and type of agricultural activities jointly determine the future distribution of agricultural emissions for each projection (van $\mathrm{Vu}$ uren et al., 2007; Wise et al., 2009; Fujino et al., 2006; Riahi et al., 2007). We use historical agricultural emissions from ACCMIP (Lamarque et al., 2010), which covers the time period of 1850-2005 and extend the historical emissions with RCP2.6 projected emissions through year 2010 for computing LULCC RFs in the year 2010.
For the TEC, agricultural emissions are derived by scaling the RCP8.5 emissions by the difference in cultivated area between the two scenarios in year 2100 . First, three latitude band average $\left(-90^{\circ}\right.$ to $-30^{\circ},-30^{\circ}$ to $30^{\circ}$, and $30^{\circ}$ to $90^{\circ}$ latitude) values of emissions of each species per unit cultivated area are computed for RCP8.5, year 2100. Next, the latitude band averages are applied to the theoretical extreme case cultivated area in the year 2100 , requiring the assumption that the practices and intensity of agriculture in the TEC are the same as in RCP8.5, and only the cultivated area changes.

\subsection{2 $\mathrm{N}_{2} \mathrm{O}$ emissions}

$\mathrm{N}_{2} \mathrm{O}$ has both industrial and agricultural sources, in addition to a large natural source from soils and oceans. Total anthropogenic $\mathrm{N}_{2} \mathrm{O}$ emissions have been estimated for the historical time period and projected for RCP4.5 (Meinshausen et al., 2011a). Additional information regarding natural emissions and also agricultural emissions is needed to partition the anthropogenic $\mathrm{N}_{2} \mathrm{O}$ emissions into LULCC and non-LULCC components and estimate the associated RFs. We follow the methodology of Meinshausen et al. (2011b), in which the $\mathrm{N}_{2} \mathrm{O}$ budget is balanced for a historical time period to extract the natural emissions from the total anthropogenic emissions. Natural emissions of $\mathrm{N}_{2} \mathrm{O}$ decrease from about 11 to $9 \mathrm{TgN}\left(\mathrm{N}_{2} \mathrm{O}\right) \mathrm{yr}^{-1}$ using this method between the years 1850 and 2000. We maintain the year 2000 emissions, $9 \mathrm{TgN}\left(\mathrm{N}_{2} \mathrm{O}\right) \mathrm{yr}^{-1}$, for the years 2000 to 2100 . Future land cover change, particularly the theoretical extreme case, could lead to further reductions in natural $\mathrm{N}_{2} \mathrm{O}$ emissions through the year 2100. However, not enough is known about global natural $\mathrm{N}_{2} \mathrm{O}$ emissions to justify changing the future emission rate for this analysis (Syakila and Kroeze, 2011).

Anthropogenic emissions of $\mathrm{N}_{2} \mathrm{O}$ have been partitioned into agricultural (LULCC) and other anthropogenic (primarily fossil fuel) sources, which have been further partitioned into animal production and cultivation sources for years prior to 2006 (Syakila and Kroeze, 2011). We compute the global $\mathrm{N}_{2} \mathrm{O}$ emitted per area covered by crop or pasture in the year 2000 using these estimates. Our estimate for year $2010 \mathrm{~N}_{2} \mathrm{O}$ emissions from agriculture, $4.3 \mathrm{TgN}\left(\mathrm{N}_{2} \mathrm{O}\right) \mathrm{yr}^{-1}$, is at the lower end of previously reported values compiled by Reay et al. (2012), ranging from 4.2 to $7 \mathrm{TgN}\left(\mathrm{N}_{2} \mathrm{O}\right) \mathrm{yr}^{-1}$. The year 2000 ratios of emission per area are applied to future changes in crop or pasture area to compute future LULCC $\mathrm{N}_{2} \mathrm{O}$ emissions for all scenarios. This assumes no future trends in the rates per cultivated land area of the major agricultural $\mathrm{N}$ sources: $\mathrm{N}$ fertilizer application and animal waste management (Syakila and Kroeze, 2011). Our approach results in increased $\mathrm{N}_{2} \mathrm{O}$ emissions from agriculture between years 2010 and 2100 for RCP2.6, RCP8.5, and the theoretical extreme case (Table 1). Emissions decrease during the 21st century in the RCP4.5 scenario and are about the same in 2100 as in 2010 for RCP6.0. 


\subsection{Radiative forcing calculations}

Radiative forcing (RF) is the change in energy balance at the top of the atmosphere due to a change in a forcing agent, such as an atmospheric greenhouse gas. It is a commonly used metric for comparison of a diverse set of climate forcings and can be used to approximate a global surface temperature response (Forster et al., 2007). The different atmospheric lifetimes of the relevant trace gas and aerosol species (listed in Fig. 2) mean that a single model approach cannot easily capture changes in all the forcing agents (Unger et al., 2010), and therefore a combination of models and methodologies is used here (Fig. 2). Here we summarize the different methodologies for computing the RFs, while detailed descriptions are given in Appendix B.

We adopt the IPCC AR5 (Myhre et al., 2013) definitions of adjusted RF and effective RF (ERF) and calculate the adjusted RFs for each forcing agent (ERFs for aerosol forcings) relative to a preindustrial state (year 1850), with modeled radiative transfer or previously published expressions. Our choice of preindustrial reference year is constrained by the available land cover change data sets, which start in 1850 . However, large-scale anthropogenic land cover change began centuries before 1850, and preindustrial changes could have an additional impact on present-day climate, perhaps accounting for nearly $10 \%$ of historical anthropogenic global surface temperature change (Pongratz and Caldiera, 2012). In our study, the RF of LULCC relative to the year 1850 is then compared to the RFs of other anthropogenic activities, dominated by fossil fuel burning. RFs due to nonLULCC activities are calculated in this study for RCP4.5 non-LULCC emissions with identical methodology to that used for LULCC emissions. All future LULCC RFs are calculated assuming background concentrations of trace gases and aerosols characteristic of RCP4.5. With this approach we can examine the impacts of the range in projected LULCC on $\mathrm{RF}$ independent of other anthropogenic activities. However, we are not able to report, for example, the RF of projected LULCC from the RCP8.5 scenario in the context of RCP8.5 fossil fuel emissions. Using a different projection to provide the background concentrations would modify the resulting LULCC RFs.

The RFs of greenhouse gases from LULCC are easily computed from changes in their atmospheric concentrations since the preindustrial period. Time-dependent changes in $\mathrm{CO}_{2}$ and $\mathrm{N}_{2} \mathrm{O}$ concentrations, which are long lived in the atmosphere, are calculated with simple, pulse-response function and box-model approaches, respectively. To model changes in concentrations of $\mathrm{O}_{3}$, which has a relatively short atmospheric lifetime, we use the CAM version 4 (Hurrell et al., 2013; Gent et al., 2011) with online chemistry from the Model for Ozone and Related chemical Tracers (MOZART) (Emmons et al., 2010), which simulates all major processes in the photochemical production and loss of $\mathrm{O}_{3}$. Our model setup also includes changes in $\mathrm{O}_{3}$ deposition rate due to
LULCC impacts on LAI through the vegetation dependence of the dry deposition rate. Results from these simulations also determine changes in the lifetime of $\mathrm{CH}_{4}$ due to LULCC emissions of NMHCs and $\mathrm{NO}_{\mathrm{x}}$.

Aerosol chemistry and dynamics are simulated on a global scale using CAM version 5 (Liu et al., 2011) with the threemode Modal Aerosol Model (MAM3) (Liu et al., 2012), including the two-moment microphysical scheme (Morrison and Gettelman, 2008) and aerosol-cloud interactions for stratiform clouds. Since models generally disagree on the magnitude of the aerosol effects, we use the IPCC-AR5 central estimate aerosol direct and indirect ERFs for the year 2011 to estimate the total anthropogenic aerosol forcing in the year 2010 and use our model results to determine the proportion of the total anthropogenic aerosols effects due to LULCC. We then apply the same scaling to the aerosol effects in all future scenarios. The impacts of the LULCC aerosol emissions, both direct effects and indirect effects on clouds, are diagnosed online within CAM5. We do not attempt to isolate the RF of aerosols from quick-responding cloud feedbacks within the model, and the computed forcings that include these feedbacks are more appropriately referred to as effective radiative forcings (ERFs). For computing a total forcing from LULCC we include the aerosol ERFs with the RFs of the remaining forcing agents.

LULCC activities change vegetation cover and type, affect forest canopy coverage, and alter wildfire activity, all of which impact land surface albedo. We compute these impacts using output from the CLM simulations with and without LULCC (Sect. 2.2). Monthly averages for solar radiation incident upon the surface (after accounting for attenuation by monthly average cloud cover) are multiplied by the surface albedo with LULCC and without LULCC for each model grid point. The RF equals the global annual average difference between the outgoing solar radiation with LULCC and without LULCC.

\subsubsection{Uncertainty}

The uncertainty in these RF estimates arises largely from the uncertainty in modeling the effects of aerosols and modeling the impacts of climate, $\mathrm{CO}_{2}$ changes, and LULCC on the carbon cycle. Our model predicts less uptake of anthropogenic carbon in natural land ecosystems compared to other land models, and thus could be underestimating the impact of land use on these regions (C. Jones et al., 2013). We compute the uncertainty in the total anthropogenic RF for each forcing agent with additional uncertainty associated with the partitioning of each RF into LULCC and other anthropogenic contributions, and with future fire emissions (Appendix C). For emissions from the theoretical extreme case we assume that our scaling assumptions (Sect. 2.3.1) are valid and do not introduce additional uncertainty, although the level of understanding of how emissions would scale under such an extreme scenario is low. 
In addition to the uncertainties, there are a few shortcomings inherent in our approach. We do not include many biogeophysical effects of LULCC, such as changes to surface latent and sensible heat fluxes and to the hydrological cycle, that impact climate (Defries et al., 2002; Feddema et al., 2005; Brovkin et al., 2006; Pitman et al., 2009; Lawrence and Chase, 2010). In general, while important for local or regional climate especially in the tropics (Strengers et al., 2010), these effects are considered minor on a global scale (Lawrence and Chase, 2010) and are difficult to quantify using the RF concept (Pielke et al., 2002). For the calculation of the many forcing agents that we do consider, our approach is to treat each forcing separately, which could lead to differences in RFs between agents that are due partly to methodology. For example, land cover changes and agricultural emissions were developed jointly for each of the RCPs, but for use in terrestrial models, including CLM, the land cover change projections were altered (Di Vittorio et al., 2014). This leads to inconsistent storylines between future emissions computed by CLM (Sect. 2.2) and those taken directly from the RCP integrated assessment model output (Sect. 2.3.1). Therefore, it is important to view the future RFs computed here as comprising a broad range in possible outcomes, extended with the TEC, as opposed to precise results corresponding to specific storylines for the future. Finally, the inhomogeneous distribution of forcing from surface albedo changes and short-lived trace gas and aerosol species could lead to non-additive (A. D. Jones et al., 2013) and highly variable local climate responses (Lawrence et al., 2012). Therefore, we use the RF for our assessment of global-scale climate impacts and acknowledge the limits of the RF concept for predicting the diverse and often local impacts of land use (Betts, 2008; Runyan et al., 2012).

\section{Results}

\subsection{Land use impacts on present-day radiative forcing}

We estimate a RF in the year 2010 from LULCC of $0.9 \pm 0.5 \mathrm{~W} \mathrm{~m}^{-2}, 40 \%( \pm 16 \%)$ of the present-day total anthropogenic RF (Fig. 3, Table 2). By separating the total anthropogenic RF (sum of LULCC and other anthropogenic activities) into contributions by forcing agent, we can compare our calculations to the central estimates of Myhre et al. (2013) (Fig. 3) and the reported RFs of van Vuuren et al. (2011) (Table 3). Our calculations of the total, presentday, anthropogenic RF correspond closely to the van Vuuren et al. (2011) values.

The major contributors to the present-day LULCC RF are associated increases in atmospheric $\mathrm{CO}_{2}$ and $\mathrm{CH}_{4}$. Deforestation, driven largely by the demand for additional agricultural land, leads to an estimated net decrease in global forest area of roughly 5.5 million $\mathrm{km}^{-2}$ from 1850 to 2010 (Lawrence et al., 2012; Fig. A1) and a transfer of carbon

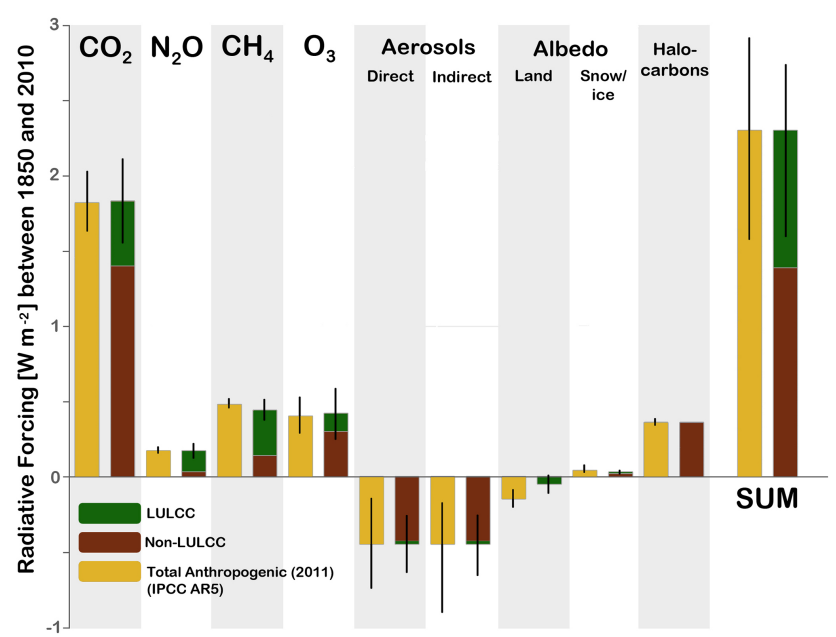

Figure 3. RFs for LULCC and other anthropogenic impacts estimated by this study for the year 2010 referenced to the year 1850 . Total anthropogenic RF from the IPCC AR5 (Myhre et al., 2013) are shown for comparison (yellow). Error lines represent $1 \sigma$ uncertainties in total anthropogenic RF for the IPCC bars and $1 \sigma$ uncertainties in LULCC RFs as computed in this study (green bars; data given in Table 2). The "SUM" bars show the total RF when all forcing agents are combined. Note that aerosol ERFs are scaled to IPCC AR5 values, as explained in the main text.

from the terrestrial biosphere into the atmosphere. Past studies report a LULCC contribution to current $\mathrm{CO}_{2}$ concentrations (either year 2000 or 2005) of $26 \mathrm{ppm}$ (Matthews et al., 2004), 22 to 43 ppm (Brovkin et al., 2004), 45 ppm (Strassmann et al., 2008), and 17 ppm (Arora and Boer, 2010). After adjusting for the $\mathrm{CO}_{2}$ fertilization feedback, we estimate a LULCC contribution of $28 \mathrm{ppm} \mathrm{CO}_{2}$ in the year 2010. Our approach results in a year $2010 \mathrm{CO}_{2}$ concentration of $399 \mathrm{ppm}$ ( $285 \mathrm{ppm}$ preindustrial, $86 \mathrm{ppm}$ fossil fuels, $28 \mathrm{ppm}$ LULCC), which overshoots the observed change in $\mathrm{CO}_{2}$ over the same period by about $10 \%$ but is within the range of values from the CMIP5 fully coupled climate model experiment: 368 to 403 ppm in 2005 (Friedlingstein et al., 2013). The overestimate is in this case attributable to uncertainty in the total LULCC $\mathrm{CO}_{2}$ emissions and uncertainty regarding the airborne fraction of historical emissions.

Present-day LULCC and non-LULCC anthropogenic activities each emit close to $150 \mathrm{Tg} \mathrm{CH}_{4}$ annually (van Vuuren et al., 2007), yet the RF from LULCC $\mathrm{CH}_{4}$ is roughly double the RF from non-LULCC $\mathrm{CH}_{4}$ (Fig. 3). The RF of nonLULCC $\mathrm{CH}_{4}$ is diminished relative to $\mathrm{LULCC} \mathrm{CH}_{4}$ by the concurrent emission of non-LULCC $\mathrm{NO}_{\mathrm{x}}$, which leads to greater tropospheric ozone $\left(\mathrm{O}_{3}\right)$ production, an increase in the oxidation capacity of the troposphere, and, as a result, a $20 \%$ reduction in $\mathrm{CH}_{4}$ lifetime with respect to removal by reaction with $\mathrm{OH}$ (Appendix $\mathrm{B} 3$ ).

From CAM4 simulations of atmospheric chemistry we find that tropospheric $\mathrm{O}_{3}$ increases from $192 \mathrm{Tg}$ in 1850 to 
Table 2. LULCC RF values and uncertainties for year 2010 and all future scenarios (year 2100) relative to the year 1850. Sum RFs are the total of all forcing agents and have been rounded to the nearest $0.1 \mathrm{~W} \mathrm{~m}^{-2}$. The theoretical extreme case is abbreviated to "TEC".

\begin{tabular}{lrrrrrr}
\hline & \multicolumn{7}{c}{ LULCC RF } \\
\cline { 2 - 7 } Forcing & 2010 & $\mathrm{R} 26$ & $\mathrm{R} 45$ & $\mathrm{R} 60$ & $\mathrm{R} 85$ & TEC \\
\hline $\mathrm{CO}_{2}$ & $0.43[ \pm 0.28]$ & $0.42[ \pm 0.54]$ & $0.29[ \pm 0.52]$ & $0.47[ \pm 0.55]$ & $0.67[ \pm 0.58]$ & $1.26[ \pm 0.67]$ \\
$\mathrm{N}_{2} \mathrm{O}$ & $0.14[ \pm 0.05]$ & $0.25[ \pm 0.09]$ & $0.18[ \pm 0.08]$ & $0.21[ \pm 0.08]$ & $0.25[ \pm 0.09]$ & $0.41[ \pm 0.13]$ \\
$\mathrm{CH}_{4}$ & $0.30[ \pm 0.07]$ & $0.18[ \pm 0.05]$ & $0.31[ \pm 0.07]$ & $0.34[ \pm 0.07]$ & $0.67[ \pm 0.12]$ & $1.56[ \pm 0.25]$ \\
Ozone & $0.12[ \pm 0.17]$ & $0.06[ \pm 0.13]$ & $0.10[ \pm 0.15]$ & $0.10[ \pm 0.15]$ & $0.17[ \pm 0.18]$ & $0.29[ \pm 0.23]$ \\
Aero DE & $-0.02[ \pm 0.19]$ & $0.03[ \pm 0.03]$ & $0.02[ \pm 0.03]$ & $0.02[ \pm 0.03]$ & $0.01[ \pm 0.05]$ & $0.08[ \pm 0.09]$ \\
Aero IE & $-0.02[ \pm 0.20]$ & $0.04[ \pm 0.14]$ & $0.01[ \pm 0.13]$ & $0.02[ \pm 0.13]$ & $0.19[ \pm 0.21]$ & $0.37[ \pm 0.29]$ \\
Albedo & $-0.05[ \pm 0.06]$ & $-0.06[ \pm 0.06]$ & $-0.06[ \pm 0.06]$ & $-0.06[ \pm 0.06]$ & $-0.03[ \pm 0.06]$ & $-0.14[ \pm 0.06]$ \\
Ice albedo & $0.01[ \pm 0.01]$ & $0.01[ \pm 0.00]$ & $0.02[ \pm 0.01]$ & $0.01[ \pm 0.00]$ & $0.01[ \pm 0.01]$ & $0.03[ \pm 0.01]$ \\
\hline Sum & $0.9[ \pm 0.5]$ & $0.9[ \pm 0.6]$ & $0.9[ \pm 0.6]$ & $1.1[ \pm 0.6]$ & $1.9[ \pm 0.7]$ & $3.9[ \pm 0.9]$ \\
$\%$ anthro. & $40[ \pm 16]$ & $21[ \pm 12]$ & $21[ \pm 11]$ & $24[ \pm 12]$ & $36[ \pm 10]$ & $53[ \pm 8]$ \\
\hline & & & & & &
\end{tabular}

Table 3. Radiative forcings $\left(\mathrm{W} \mathrm{m}^{-2}\right.$ ) for the year 2010 and the year 2100 compared to Myrhe et al. (2013) and van Vuuren et al. (2011), respectively. For year 2100 we show the RF from RCP4.5 scenario emissions (referenced to year 1850) estimated from the modeling results in this study and from van Vuuren et al. (2011).

\begin{tabular}{lrrrr}
\hline & & & Total & \\
2010 & LULCC & Non-LULCC & anthro. & Myhre et al. (2013) \\
\hline Total & 0.91 & 1.39 & 2.3 & 2.22 \\
$\mathrm{CO}_{2}$ & 0.43 & 1.4 & 1.83 & 1.82 \\
$\mathrm{CH}_{4}$ & 0.3 & 0.14 & 0.44 & 0.48 \\
$\mathrm{~N}_{2} \mathrm{O}$ & 0.14 & 0.03 & 0.17 & 0.17 \\
Halocarbons & 0 & 0.36 & 0.36 & 0.36 \\
Aerosols $/ \mathrm{O}_{3} /$ alb $^{*}$ & 0.04 & -0.54 & -0.5 & -0.61 \\
\hline $2100-\mathrm{RCP} 4.5$ & & & & van Vuuren et al. (2011) \\
\hline Total & 0.92 & 3.49 & 4.41 & 4.14 \\
$\mathrm{CO}_{2}$ & 0.29 & 3.17 & 3.46 & 3.47 \\
$\mathrm{CH}_{4}$ & 0.31 & 0.12 & 0.43 & 0.37 \\
$\mathrm{~N}_{2} \mathrm{O}$ & 0.18 & 0.12 & 0.3 & 0.31 \\
Halocarbons & 0 & 0.18 & 0.18 & 0.18 \\
Aerosols $/ \mathrm{O}_{3} /$ alb* & 0.14 & -0.1 & 0.04 & -0.19 \\
\hline
\end{tabular}

* This sum RF includes aerosols (direct effects, indirect effects on clouds, and deposition onto snow/ice surfaces), tropospheric $\mathrm{O}_{3}$, and forcing from surface albedo changes.

$304 \mathrm{Tg}$ in 2010, when all anthropogenic activities are included. The $\mathrm{O}_{3}$ increase of $112 \mathrm{Tg}$ falls within the range of previous estimates (Lamarque et al., 2005). Here we separate the increase in $\mathrm{O}_{3}$ concentrations into a non-LULCC contribution, $87 \%$, and a LULCC contribution, $13 \%$. The large non-LULCC contribution is attributable to additional $\mathrm{O}_{3}$ formation from $\mathrm{NO}_{\mathrm{x}}$ emissions from fossil fuel burning sources. The contribution of LULCC to changes in $\mathrm{O}_{3}$ combines several competing effects (Ganzeveld et al., 2010), including attributed changes in biogenic emissions of volatile organic compounds (virtually no contribution by historical LULCC on a global average) and reductions in emissions from wildfires (Table 1). The increase in tropospheric $\mathrm{O}_{3}$ from LULCC is partially compensated for by a slight increase in the dry de- position of $\mathrm{O}_{3}$ with LULCC (6\%) between 1850 and 2010 as a result of the LULCC-enhanced $\mathrm{O}_{3}$ concentration and despite the decrease in $\mathrm{O}_{3}$ removal efficiency in deforested areas, similar to the findings of Ganzeveld et al. (2010). The small contribution of LULCC to global "short-lived" $\mathrm{O}_{3}$ concentrations is augmented by additional $\mathrm{O}_{3}$ (2.5 DU in 2010) produced in response to long-term increases in $\mathrm{CH}_{4}$ (primary mode response, Appendix B2). The additional $\mathrm{O}_{3}$ from this response accounts for $60 \%$ of the LULCC $\mathrm{O}_{3} \mathrm{RF}$ of $0.12 \mathrm{~W} \mathrm{~m}^{-2}$ in 2010 . The primary mode response $\mathrm{O}_{3}$ is less important for non-LULCC activities because of the smaller $\mathrm{CH}_{4}$ contribution from these activities.

We assume that long-lived greenhouse gases, i.e., $\mathrm{CO}_{2}$, $\mathrm{CH}_{4}$, and $\mathrm{N}_{2} \mathrm{O}$, with lifetimes on the order of years to 
Table 4. Quantiles of the spatial distribution of the different forcings from historical LULCC (assessed in 2010) when represented as a probability density function. The grid spacing is $1.9^{\circ}$ latitude by $2.5^{\circ}$ longitude. Note that we show aerosol optical depth (AOD) in place of the aerosol forcings since the distribution of these forcings includes variability in cloud properties that are not directly attributable to changes in aerosols at this grid spacing.

\begin{tabular}{lrrrrrrrr}
\hline & \multicolumn{7}{c}{ Quantiles } \\
\cline { 2 - 8 } Forcing & Mean & Min. & $\mathrm{q}_{0.1}$ & $\mathrm{q}_{0.25}$ & Median & $\mathrm{q}_{0.75}$ & $\mathrm{q}_{0.9}$ & Max. \\
\hline $\mathrm{CO}_{2}$ & $0.43[ \pm 0.27]$ & 0.43 & 0.43 & 0.43 & 0.43 & 0.43 & 0.43 & 0.43 \\
$\mathrm{~N}_{2} \mathrm{O}$ & $0.14[ \pm 0.04]$ & 0.14 & 0.14 & 0.14 & 0.14 & 0.14 & 0.14 & 0.14 \\
$\mathrm{CH}_{4}$ & $0.30[ \pm 0.07]$ & 0.3 & 0.3 & 0.3 & 0.3 & 0.3 & 0.3 & 0.3 \\
Ozone & $0.12[ \pm 0.18]$ & -0.10 & 0.06 & 0.08 & 0.11 & 0.15 & 0.19 & 0.37 \\
Albedo* & $-0.05[ \pm 0.12]$ & -5.6 & -0.45 & -0.09 & 0 & 0 & 0.08 & 2.5 \\
Ice alb. & $0.01[ \pm 0.02]$ & -1.52 & -0.01 & 0 & 0 & 0.01 & 0.06 & 2.6 \\
\hline Non-forcing quantity & & & & & & & & \\
\hline AOD & 0.005 & -0.18 & -0.02 & 0 & 0.03 & 0.07 & 0.11 & 0.29 \\
\hline
\end{tabular}

* The spatial distribution of the RF from albedo changes is computed only for land points.

centuries, are sufficiently well mixed in the atmosphere that the forcing from these gases is spatially homogeneous (Table 4). The lifetime of tropospheric $\mathrm{O}_{3}$ is considerably shorter, on the order of weeks, meaning concentrations can vary spatially, becoming higher near areas of $\mathrm{O}_{3}$ production and remaining below the global average in remote regions away from areas of $\mathrm{O}_{3}$ production. The RF varies in space with the concentration, although these heterogeneities are moderate for $\mathrm{O}_{3}$. The $\mathrm{RF}$ at $80 \%$ of grid points is within $\pm 0.07 \mathrm{~W} \mathrm{~m}^{-2}$ of the global mean RF (Table 4).

While the positive RF from non-LULCC greenhouse gas emissions is offset to some extent by concurrent emissions of aerosols, LULCC contributes both increases and decreases in aerosol emissions resulting in nearly neutral aerosol RFs for the present day (Fig. 3). These opposing contributions to aerosol emissions are evident in the spatial variability in AOD attributable to historical LULCC, ranging between -0.18 and 0.29 (Table 4). Global average aerosol optical depth (AOD) is greater in 2010 and in 2100 for the RCP4.5, RCP6.0, and TEC scenarios when LULCC emissions are included, and lower for RCP2.6 and RCP8.5 scenarios, but in all cases the attributed share of LULCC is less than 0.01 . The RF from aerosol deposition onto snow and ice surfaces is negligible on a global average $\left(0.01 \mathrm{~W} \mathrm{~m}^{-2}\right.$ for historical LULCC) but exceeds $\pm 1 \mathrm{~W} \mathrm{~m}^{-2}$ in some locations (Table 4). We also consider the impacts of aerosols and trace gas species on atmospheric $\mathrm{CO}_{2}$ due to bio-fertilization by deposition of $\mathrm{P}, \mathrm{Fe}$, and $\mathrm{N}$ emitted from fires, and $\mathrm{N}$ from agriculture $\left(\mathrm{NH}_{3}, \mathrm{NO}_{\mathrm{x}}, \mathrm{N}_{2} \mathrm{O}\right)$. For present-day emissions of these species from LULCC activities (and land cover change impacts on fires), the drawdown of $\mathrm{CO}_{2}$, enhanced particularly by agricultural emissions of $\mathrm{N}$, leads to a negative $\mathrm{RF}$ of $-0.10 \mathrm{~W} \mathrm{~m}^{-2}$ that nearly compensates for the positive $\mathrm{RF}$ from the greenhouse effect of agricultural $\mathrm{N}_{2} \mathrm{O}$ emissions $\left(0.14 \mathrm{~W} \mathrm{~m}^{-2}\right)$, a noteworthy aspect of agricultural emissions that was also suggested by Zaehle et al. (2011).

Estimates for the global RF from albedo changes range from -0.10 (Skeie et al., 2011) to $-0.28 \mathrm{~W} \mathrm{~m}^{-2}$ (Lawrence et al., 2012), with a substantial percentage, potentially $25 \%$, caused by preindustrial LULCC (Pongratz et al., 2009). Further estimates (Betts, 2001; Betts et al., 2007; Davin et al., 2007) fall near the IPCC AR5 central estimate of $-0.15 \mathrm{~W} \mathrm{~m}^{-2}$ (Myhre et al., 2013). The RF from albedo changes is near zero in most locations but has a high magnitude, up to $5 \mathrm{~W} \mathrm{~m}^{-2}$, in some localities on an annual average (Table 4), similar to the findings of Betts et al. (2007). Our estimate for the global RF from historical land surface albedo change, $-0.05 \mathrm{~W} \mathrm{~m}^{-2}$, is at the higher end of the range of previously published estimates, yet still within the $90 \%$ confidence interval around the central estimate of Myhre et al. (2013). Reductions in fire area burned that result from historical LULCC act to decrease the magnitude of the surface albedo change forcing, although by less than $0.01 \mathrm{~W} \mathrm{~m}^{-2}$ for the present day. The use of a less altered, more natural background state than our year 1850 landscape would likely increase the magnitude of this forcing (Sitch et al., 2005; Pongratz et al., 2009).

\subsection{Future land use impacts on radiative forcing}

In the year 2100 the RF attributable to anthropogenic LULCC, as projected by the RCPs, ranges between 0.9 and $1.9 \mathrm{~W} \mathrm{~m}^{-2}$ (Fig. 4), although, as a percentage of the projected total anthropogenic RF (as computed for RCP4.5), land use is less important in year 2100 than in 2010 (Table 2). Despite diverging trajectories for forest area and crop area for RCP2.6, RCP4.5, and RCP6.0 in the 21st century (Fig. A1), the year 2100 LULCC RFs are similar between these scenarios (Fig. 4). The RCP8.5 RF is characterized by relatively high contributions from $\mathrm{CO}_{2}$ and $\mathrm{CH}_{4}$ resulting in a total 
LULCC RF that is double the average of the other three RCP scenarios. The difference between RCP8.5 and the other scenarios suggests that decisions regarding global land policy similar to those used to develop the RCPs could reduce or increase global anthropogenic RF by $1 \mathrm{~W} \mathrm{~m}^{-2}$ by 2100 .

The LULCC projections for all four RCP scenarios include future decreases in global deforestation rates compared to recent historical rates (Fig. 5). A recent satellite assessment of global forest area gain and loss reported a global forest loss rate of $12.5 \mathrm{Mha} \mathrm{yr}^{-1}$ between 2000 and 2012 (Hansen et al., 2013), suggesting the census-reported rates for 2000 to 2010 (FAO, 2010) may be estimating less deforestation than is really occurring. If recent rates of observed forest area change persist, the global forest area projected in all four RCP scenarios by Hurtt et al. (2011) will become overestimates in the near future, especially in RCP4.5 and RCP6.0. More extreme land use scenarios are plausible, and would have a larger effect on climate. The theoretical extreme case, in which all arable land is converted to agricultural land and all remaining land that is pasturable is converted to grasses by the year 2100, does not take some important agricultural factors, such as changes in crop yields and per capita caloric intake, into account, but was created to represent a limit to cropland expansion on Earth. Since we designate arable land using a measure of climate suitability (Appendix A), following Ramankutty et al. (2002), crop area could conceivably expand beyond this limit with the use of irrigation. In fact, areas of South Asia currently support more agriculture than estimates of climate suitability suggest they should (Ramankutty et al., 2002).

In the theoretical extreme case, crop area roughly doubles by the year 2050, and continues to increase at the same rate to 2100. The rate of deforestation required to accommodate the expanded agriculture is 3 times greater than upper estimates from the RCPs for year 2000-2030 forest loss (Fig. 5), resulting in the near-complete removal of tropical forests by the year 2100 (Fig. A2) and a global release of $\sim 500 \mathrm{PgC}$ from vegetation to the atmosphere. Loss of soil carbon often accompanies forest conversion to crops or grasses (Lal, 2004), but this process is not well simulated in this generation of terrestrial models. House et al. (2002) estimate terrestrial carbon loss from a complete deforestation to be between 450 and $820 \mathrm{PgC}$, with much of the uncertainty in the range due to different estimates of carbon loss from soils. The version and configuration of CLM used in this study does not include the process of carbon loss from soils from cultivation. Still, loss of carbon from vegetation alone in the theoretical extreme case corresponds to roughly two-thirds of the value of the proven reserves of fossil fuels (760 PgC) (Meinshausen et al., 2009). The substantial loss of terrestrial carbon to the atmosphere in the theoretical extreme case leads to a RF of $1.3 \mathrm{~W} \mathrm{~m}^{-2}$ for $\mathrm{CO}_{2}$ (Fig. 4). The magnitudes of all other forcing agents are enhanced in this scenario, leading to a sum RF of $3.9 \pm 0.9 \mathrm{~W} \mathrm{~m}^{-2}$ at the year 2100 .

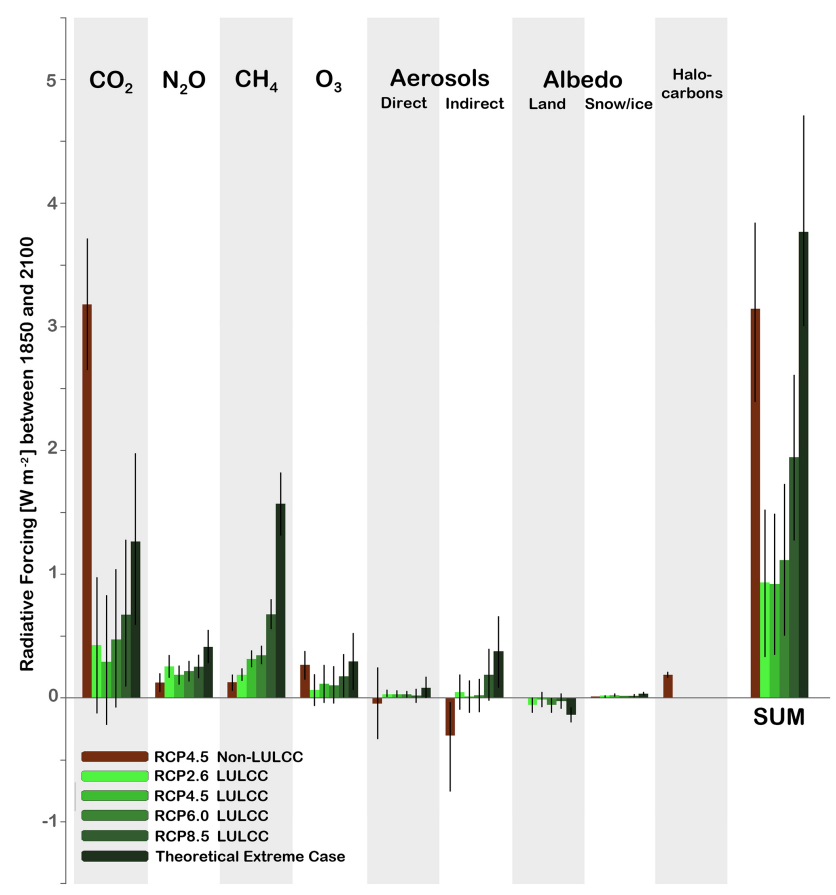

Figure 4. RF for all LULCC and non-LULCC anthropogenic impacts (RCP4.5 Non-LULCC) estimated by this study for the year 2100 , referenced to the year 1850 . Error bars show $1 \sigma$ uncertainties as computed in this study (Table 2). The "SUM" bars show the total $\mathrm{RF}$ when all forcing agents are considered.

\subsection{Enhancement of land use $\mathrm{CO}_{2}$ radiative forcing}

On average over all converted land types and land management histories, $\mathrm{CO}_{2} \mathrm{RF}$ from LULCC is enhanced by the accompanying (although not necessarily concurrent) emissions of non- $\mathrm{CO}_{2}$ greenhouse gases and aerosols, such that the total RF is 2 to 3 times that of the $\mathrm{CO}_{2}$ alone. For example, we estimate the net carbon flux from LULCC between 1850 and 2010 to be $140 \mathrm{PgC}$, leading to a $\mathrm{RF}$ from $\mathrm{CO}_{2}$ of $\sim 0.4 \mathrm{~W} \mathrm{~m}^{-2}$ in 2010 , or about half of the total LULCC RF. In contrast, for other anthropogenic activities the RF from $\mathrm{CO}_{2}$ and the total RF are roughly equal (Figs. 3, 4). Therefore, while LULCC accounted for about $20 \%$ of anthropogenic $\mathrm{CO}_{2}$-equivalent emissions in 2010 (Tubiello et al., 2013), its contribution to the anthropogenic RF is $40 \%$ $( \pm 16 \%)$. We can express this enhancement factor as the ratio of the sum RF to the $\mathrm{CO}_{2} \mathrm{RF}$ for LULCC, divided by the same ratio for other anthropogenic activities $(\mathrm{FF}+)$, or $E=\left(\mathrm{RF}_{\text {sum }} / \mathrm{RF}_{\mathrm{CO}_{2}}\right)_{\mathrm{LULCC}} /\left(\mathrm{RF}_{\text {sum }} / \mathrm{RF}_{\mathrm{CO}_{2}}\right)_{\mathrm{FF}+}$. For all future LULCC scenarios the enhancement factor is between 2.0 and 2.9 (Table 5). We compute the maximum enhancement of the $\mathrm{CO}_{2} \mathrm{RF}$ for the RCP4.5 scenario $(E=2.9)$. In the development of the RCP4.5 scenario, international carbon trading incentivizes preservation of forests and reforestation, which reduces $\mathrm{CO}_{2}$ emissions and the resulting $\mathrm{CO}_{2} \mathrm{RF}$ from LULCC, increasing the enhancement factor. 


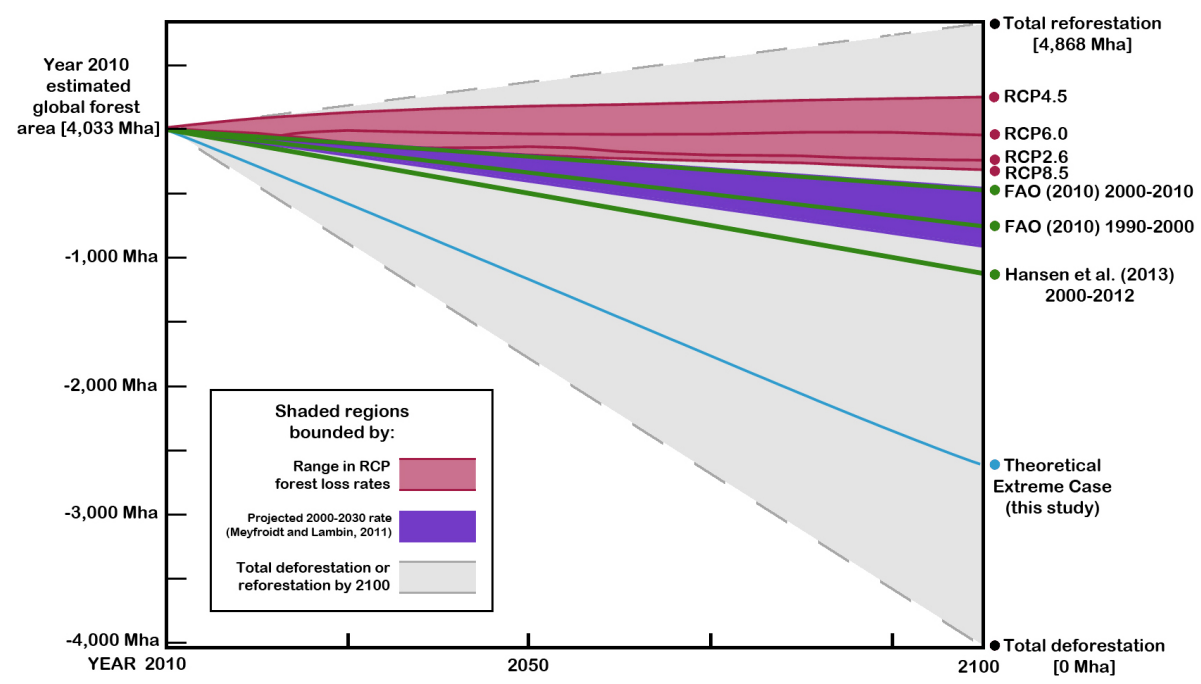

Figure 5. Comparison of projected annual rates of forest area change. Colored lines and shading represent the change in global forest area between 2010 and 2100 for the Representative Concentration Pathways (red) and the theoretical extreme case (light blue). The grey shaded region is bounded by the annual rate of forest area change required to completely reforest to the estimated prehistoric forest area (Pongratz et al., 2008), or remove all forests by year 2100. Reported and projected forest area change from Meyfroidt and Lambin (2011) (purple) and FAO (2010) and Hansen et al. (2013) (green) are depicted as constant rates through year 2100 to show the result if these rates were sustained.

Table 5. Enhancement of $\mathrm{CO}_{2}$ RF by other forcing agents for LULCC and non-LULCC activities. RFs are given in units of $\mathrm{W} \mathrm{m}^{-2}$.

\begin{tabular}{lrrrrr}
\hline & \multicolumn{2}{c}{ LULCC } & \multicolumn{2}{c}{ Non-LULCC $^{\mathrm{a}}$} & \\
\cline { 2 - 5 } Scenario & CO2 RF & TOTAL RF & CO2 RF & TOTAL RF & Enhancement \\
\hline 2010 & 0.43 & 0.91 & 1.4 & 1.39 & $2.1(+1.0,-0.5)$ \\
RCP2.6 & 0.42 & 0.93 & 3.17 & 3.49 & $2.0(+1.4,-0.7)$ \\
RCP4.5 & 0.29 & 0.92 & 3.17 & 3.49 & $2.9(+2.6,-1.6)$ \\
RCP6.0 & 0.47 & 1.11 & 3.17 & 3.49 & $2.1(+1.5,-0.7)$ \\
RCP8.5 & 0.67 & 1.94 & 3.17 & 3.49 & $2.6(+1.8,-0.8)$ \\
TEC $^{\text {c }}$ & 1.26 & 3.86 & 3.17 & 3.49 & $2.8(+1.3,-0.6)$ \\
\hline
\end{tabular}

a Other anthropogenic activities, dominated by fossil fuel burning, and including the aerosol effects RFs from the IPCC AR5 (Myhre et al., 2013). ${ }^{\mathrm{b}}$ Enhancement is defined as the ratio of total RF to $\mathrm{CO}_{2}$ RF for LULCC divided by the ratio of total $\mathrm{RF}$ to $\mathrm{CO}_{2} \mathrm{RF}$ for $\mathrm{FF}+.^{\mathrm{c}}$ Theoretical extreme case.

The uncertainties in this factor (computed using the Monte Carlo method as described in Appendix C3) are large but suggest that the enhancement is unlikely to be less than 1.3 for the year 2010 or any of the given future scenarios. Values above 4.0 for the enhancement factor are within the uncertainty range for the RCP4.5, RCP8.5, and TEC scenarios. The large enhancement factors for the RCP8.5 and TEC scenarios result mainly from the substantial $\mathrm{CH}_{4} \mathrm{RF}$ relative to the $\mathrm{CO}_{2}$ RF. For RCP4.5, this is a reflection of the low $\mathrm{CO}_{2}$ $\mathrm{RF}$ attributed to LULCC and relatively high total RF with contributions from all other non- $\mathrm{CO}_{2}$ greenhouse gases. The aerosol forcings play a minor role in the sum RF attributed to LULCC but impact the enhancement factor by reducing the non-LULCC forcing considerably. The aerosol ERFs are the source of much of the uncertainty surrounding the enhancement factor. Since the RF calculations presented here are within uncertainty estimates across many models and estimates (Fig. 3), it is likely that other models or approaches would obtain similar results if the same processes and activities were considered. We do not expect that the LULCC activities and biogeophysical forcings that we exclude from this study would have a substantial impact on the enhancement as these forcings have been shown to be small when considered on a global scale (Lawrence and Chase, 2010). Including model representation of LULCC impacts on soil carbon could increase the $\mathrm{CO}_{2}$ and total RF attributed to LULCC (Levis et al., 2014) and lead to a small reduction in the enhancement factors compared to the values we report. 


\section{Conclusions}

Effective strategies for mitigation of human impacts on global climate require an understanding of the major sources of those impacts (Unger et al., 2010). Anthropogenic land use and changes to land cover have long been recognized as important contributors to global climate forcing (Feddema et al., 2005), and yet most studies on this topic focus on either land use (e.g., Unger et al., 2010) or land cover change (e.g., Davin et al., 2007; Pongratz et al., 2009), but not both. In this study we compute the fraction of anthropogenic RF that is attributable to LULCC activities including a more comprehensive range of forcing agents.

Current estimates of the net LULCC carbon flux between 1850 and 2000 are between 108 and $188 \mathrm{PgC}$ (Houghton, 2010), while here we estimate $131 \mathrm{PgC}$. Estimates from this study using the future scenarios analyzed in the IPCC (the Representative Concentration Pathway, RCP, scenarios) suggest between 20 and $210 \mathrm{PgC}$ carbon will be released, consistent with Strassmann et al. (2008), and at the higher end of the model range reported by Brovkin et al. (2013). Our model underpredicts the uptake of land carbon relative to other models (e.g Arora et al., 2013), and unlike other estimates includes the explicit interplay between changes in land use and fires (e.g., Marlon et al., 2008; Kloster et al., 2010). The RCP scenarios were designed to cover a diverse set of pathways and create a broad range in possible outcomes for the next century (Moss et al., 2010). Given that the RCP scenarios all project decreases in global forest area loss rates in the 21 st century relative to current rates, these scenarios are likely to be lower bounds on deforestation rates in the future (Fig. 5). To explore higher rates of global forest loss and crop and pasture expansions, we introduce a theoretical extreme case, in which all the arable land is converted to agriculture and pasture usage by 2100 . Since the rates of deforestation in this scenario are higher than current rates, this scenario is an upper bound on what could occur. With the intense pressures on land inherent to this scenario, we calculate that between 590 and $700 \mathrm{PgC}$ would be released from LULCC in this century.

We find that the total RF contributed by LULCC is 2 to 3 times the $\mathrm{RF}$ from $\mathrm{CO}_{2}$ alone when additional positive forcings from non- $\mathrm{CO}_{2}$ greenhouse gases and relatively small forcings from aerosols and surface albedo are considered. The RF of other anthropogenic activities (largely fossil fuels) in 2010 and in 2100 (RCP4.5), relative to 1850, includes a large magnitude negative aerosol forcing that offsets enough of the warming contribution from greenhouse gases that the total RF matches closely with the RF from $\mathrm{CO}_{2}$. The result of this enhancement of the LULCC RF with respect to its $\mathrm{CO}_{2}$ emissions, and lack of enhancement of the other anthropogenic activities RF, is a $40 \%$ LULCC contribution to present-day anthropogenic RF, a substantially larger percentage that is deduced from greenhouse gas emissions alone (Tubiello et al., 2013). The percentage of anthropogenic RF attributable to LULCC activities is likely to decrease in the future, even as the magnitude of the RF could increase by up to $1.0 \mathrm{~W} \mathrm{~m}^{-2}$ from 2010 to 2100 . The lifetime and distribution of short-lived species makes simplification difficult in terms of equating $\mathrm{CO}_{2} \mathrm{RF}$ to other constituents (Shine et al., 2007), but simple approaches of controlling cumulative carbon (Allen et al., 2009) should account for the 2 to 3 times enhancement of the LULCC RF over long time periods per unit $\mathrm{CO}_{2}$ emitted relative to other sources of $\mathrm{CO}_{2}$.

Including forcings from aerosols in our assessment, while only slightly affecting the mean estimate of the total LULCC RF, greatly increases the uncertainty in the estimate. Much of the uncertainty arises from the simulation of aerosol-cloud interactions and the indirect effect for which very little model consensus exists on a global scale (Forster et al., 2007). In addition to these uncertainties, the perturbations of natural aerosol emissions by LULCC activities (mineral dust, SOA, wildfire smoke) are only beginning to be better understood on a global scale (Ginoux et al., 2012; Ganzeveld et al., 2010). Further research into the sources and lifetimes of natural aerosols, as well as anthropogenic impacts on their emissions, could efficiently reduce our uncertainty in the contribution of LULCC to global RF.

While it is likely that advances in, and proliferation of, agricultural technologies will be sufficient to meet global food demand without such an extreme increase in crop and pasture area, investment in foreign lands for agriculture, as a cost-effective alternative to intensification of existing agriculture, may be hastening the conversion of unprotected natural lands (Rulli et al., 2013). Given the huge potential for climate impacts from LULCC in this century, estimated here to be $3.9 \pm 0.9 \mathrm{~W} \mathrm{~m}^{-2}$ at the maximum, similar to some estimates of future climate impacts from fossil fuels (e.g., van Vuuren et al., 2011), our study substantiates that not only energy usage but also land use and land cover change need to remain a focus of climate change mitigation. 
Appendix A: Crop suitability calculations for theoretical extreme case

To estimate the maximum extent of crop and pasture for the theoretical extreme future scenario requires criteria that measure the potential of a land area to support agriculture. We follow the methodology of Ramankutty et al. (2002) to define the suitability of the climate and soil properties at model grid point locations for crops or pasture. In that study the authors define suitability based on the growing degree days, moisture index, soil organic carbon content, and soil $\mathrm{pH}$ that are characteristic of present-day agricultural areas. Areas with a long enough growing season and sufficient water resources to support present-day crops, without irrigation (which is not included in their analysis), are considered suitable based on climate. For both soil organic carbon content and soil $\mathrm{pH}$ the authors find an ideal range of values that support agriculture and categorize areas that meet the criteria as suitable based on the soil. We repeat their analysis with temperature and precipitation data from the Climatic Research Unit TS3.10 data set (Harris et al., 2014), soil data from the International Soil Reference and Information Centre - World Soil Information database (Batjes, 2005), and a simplified moisture index (Willmott and Feddema, 1992).

In this approach, sigmoidal functions are fit to probability density functions of grid box fractional crop area and four environmental factors: growing degree days (GDD), moisture index, soil $\mathrm{pH}$, and soil organic carbon density. These functions describe where crops grow in today's world and how well they grow there. The functions are then applied to current global climate and soil data sets to identify areas that could support crops but have yet to, and also some areas where crops outdo their potential based on the local climate and soil, usually due to irrigation.

We use the Ramankutty et al. (2002) definitions for soil $\mathrm{pH}$; soil carbon, defined as the mass of carbon per meter squared in the top $30 \mathrm{~cm}$ of the non-gravel soil; and GDD, defined as the number of ${ }^{\circ} \mathrm{C}$ by which daily mean temperature exceeds $5^{\circ} \mathrm{C}$.

For the moisture index we use the climate moisture index (CMI) (Willmott and Feddema, 1992) which is defined using precipitation, $P$, and potential evaporation, $\mathrm{PE}$, data as

$$
\begin{array}{ll}
\mathrm{CMI}=1-\mathrm{PE} / P & \text { when } P \geq \mathrm{PE} \\
\mathrm{CMI}=P / P \mathrm{PE}-1 & \text { when } P<\mathrm{PE} \\
\mathrm{CMI}=0 & \text { when } P=\mathrm{PE}=0 .
\end{array}
$$

We use 1979-2009 averages for climate variables and year 2000 crop area data (Ramankutty et al., 2008). For fitting the individual sigmoidal curves, we restrict the data to only those points that are otherwise optimal for crops, as in Ramankutty et al. (2002). For example, when fitting the CMI data, we restrict the crop area data to regions where the GDD, soil carbon, and soil $\mathrm{pH}$ support crops. This isolates grid points that could be CMI limited.

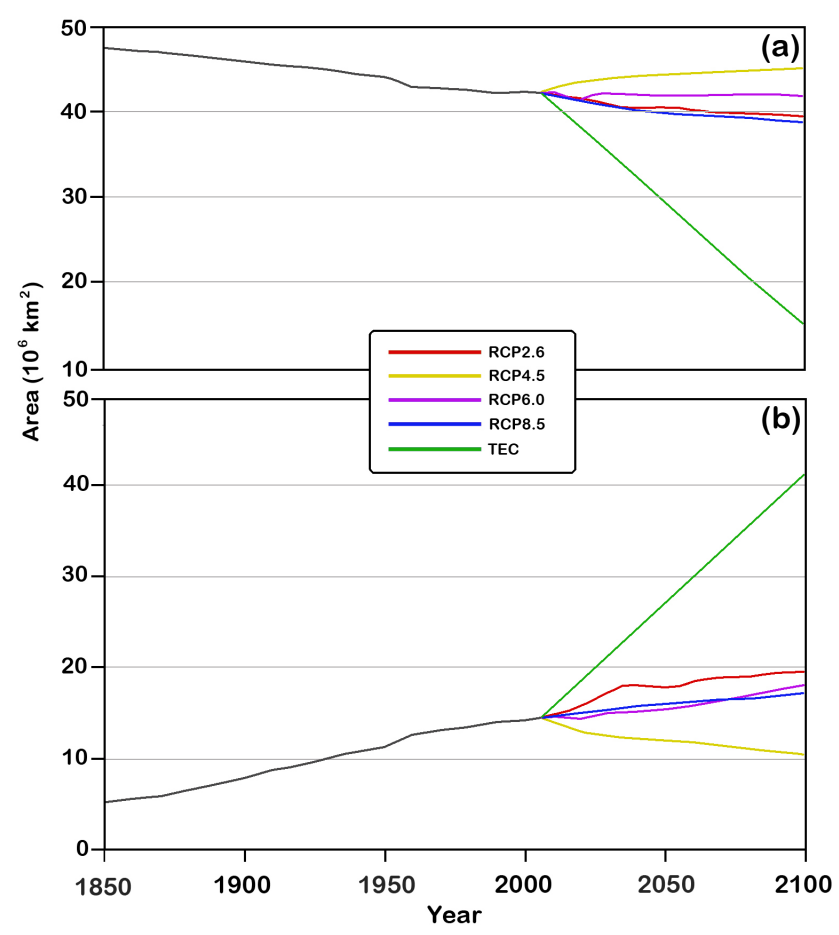

Figure A1. Change in global total (a) forest and (b) crop areal coverage with time for historical and Representative Concentration Pathway scenarios (Lawrence et al., 2012) and the theoretical extreme case (TEC, green).

Following Ramankutty et al. (2002), we fit a single sigmoidal curve to the GDD data and the CMI data, a double sigmoidal curve to the soil carbon data, and explicitly define a $\mathrm{pH}$ limit function. The expressions for these functions from Ramankutty et al. (2002) are given below with new coefficients computed for our study:

$f_{1}(\mathrm{GDD})=\frac{1}{\left[1+e^{a(b-\mathrm{GDD})}\right]} ;$

$f_{2}(\alpha)=\frac{1}{\left[1+e^{c(d-\alpha)}\right]}$,

where $a=0.0037, b=1502, c=10.16$, and $d=0.3544$;

$g_{1}\left(C_{\text {soil }}\right)=\frac{a}{\left[1+e^{b\left(c-C_{\text {soil }}\right)}\right]} \frac{a}{\left[1+e^{d\left(h-C_{\text {soil }}\right)}\right]}$,

where $a=22.09, b=3.759, c=1.839, d=0.0564$, and $h=106.5$;

$g_{2}\left(\mathrm{pH}_{\text {soil }}\right)=\left\{\begin{array}{lll}-1.64+0.41 \mathrm{pH}_{\text {soil }} & \text { if } & \mathrm{pH}_{\text {soil }} \leq 6.5 \\ 1 & \text { if } & 6.5<\mathrm{pH}_{\text {soil }}<8 \\ 1-2\left(\mathrm{pH}_{\text {soil }}-8\right) & \text { if } & \mathrm{pH}_{\text {soil }} \geq 8\end{array}\right.$

These functions are multiplied together to create suitability indices: the product of the $f$ functions gives the climate 

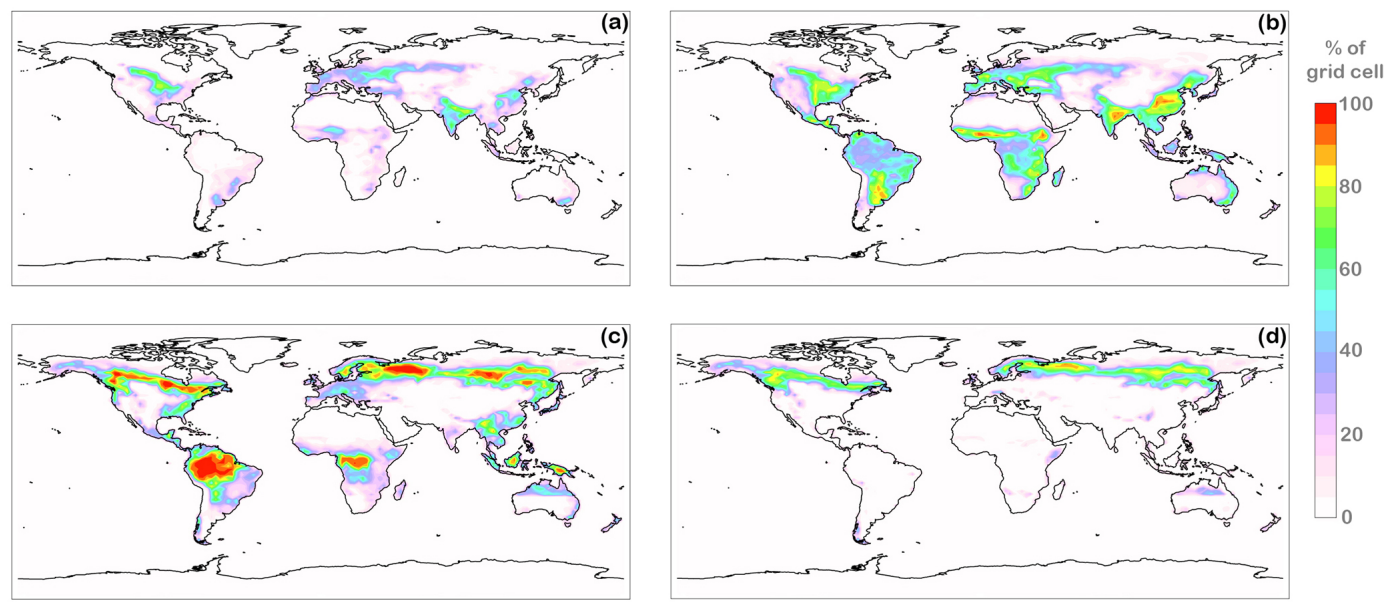

Figure A2. Percent of grid box area consisting of (a) year 2010 crops, (b) potential crops based on climate and soil suitability, (c) year 2010 forests, and (d) year 2100 forests in the theoretical extreme case.

suitability index and the product of the $g$ functions gives the soil suitability index. Natural land that is "suitable" for crops based on these criteria is converted to cropland (on a linear year-to-year basis) between years 2006 and 2100. We assume area that is suitable for crops based on climate, but not soil characteristics, can support grass and is used for pasturing animals. This assumption leads to the replacing of most tropical forests by crops or grasslands. The global potential crop area computed here for present-day climate is $4180 \mathrm{Mha}$ and the potential pasture area is $3110 \mathrm{Mha}$, compared to reported year 2010 utilized areas of 1570 Mha for crops and 2030 Mha for pasture (Hurtt et al., 2011). Published estimates of potential crop area range from 1552 to 5131 Mha (Eitelberg et al., 2014). Our estimate for potential crop area would be classified as "high" within this range (Eitelberg et al., 2014), most similar to the results of Bruinsma (2003).

Since the potential crop area depends on climate, it is likely to change in the future. One estimate, using a businessas-usual greenhouse gas emissions scenario, yields a $16 \%$ increase of the 1961-1990 potential crop area by 2070-2099, mainly in high latitudes (Ramankutty et al., 2002). We did not include climate-dependent trends in potential crop area in this study but note here that doing so may increase the year $2100 \mathrm{RF}$ of the theoretical extreme case LULCC.

The PFT time series for the theoretical extreme case is put together as follows. First, the potential crop area and potential pasture area are used to give the year 2100 crop area and minimum grassland area, respectively. Crop area is increased linearly starting in year 2006 at the expense of grassland first, then shrubs, then forest area. Pasture is increased at the expense of shrubs, then forest area. Different PFTs within those general categories are lost or gained in proportion to their year 2006 fractions. In this scenario, global crop area increases $200 \%$ with substantial expansion into tropical Africa and South America, and southeast Asia (Figs. A1, A2). The expansion of crops and pasture into the tropics occurs at the expense of forests, which have virtually disappeared from the tropics by the year 2100 (Fig. A2). Global forest area decreases by $65 \%$ in the theoretical extreme case. Emissions of $\mathrm{CH}_{4}$ and $\mathrm{N}_{2} \mathrm{O}$ from agriculture in the theoretical extreme case are based on emissions of these gases per area of crop/pasture in the RCP8.5 scenario and scaled by the differences in crop and pasture area between RCP8.5 and the theoretical extreme case. We do not consider possible future changes in natural emissions of $\mathrm{CH}_{4}$ and $\mathrm{N}_{2} \mathrm{O}$.

\section{Appendix B}

This appendix includes the details of the methods that we used to compute the RFs of all forcing agents from the LULCC emissions described in Sects. 2.2 and 2.3. For atmospheric constituents the methods for computing the change in atmospheric concentrations are explained first, followed by the calculations for the RF.

\section{$\mathrm{B1} \mathrm{CO}_{2}$}

$\mathrm{CO}_{2}$ is chemically inert in the atmosphere but, over time, the airborne fraction of emitted $\mathrm{CO}_{2}$ decreases as ocean and land uptake of carbon occurs. Therefore, the most recent $\mathrm{CO}_{2}$ emissions will have the highest airborne fraction. We apply a $\mathrm{CO}_{2}$ pulse response function (Enting et al., 1994) to compute the airborne fraction of the yearly pulse emissions at the year 2010 or 2100 , following previously used methods (e.g., Randerson et al., 2006; Ward et al., 2012). This weighting is especially important for non-LULCC emissions, which have been largest over the most recent decades. 
After changes in the $\mathrm{CO}_{2}$ concentration due to LULCC or other anthropogenic emissions are calculated, simple expressions from the IPCC TAR (Ramaswamy et al., 2001) can be used to estimate the adjusted radiative forcing $(\Delta F)$. For $\mathrm{CO}_{2}$,

$\Delta F=5.35 \cdot \ln \left(\frac{C}{C_{\mathrm{O}}}\right)$.

Here $C_{\mathrm{O}}$ is the atmospheric $\mathrm{CO}_{2}$ concentration in the unperturbed state (with no LULCC emissions, or no emissions from other anthropogenic activities) and $C$ is the perturbed atmospheric $\mathrm{CO}_{2}$ concentration containing all anthropogenic contributions. In this way the $\mathrm{CO}_{2}$ saturation effect of the different perturbed $\mathrm{CO}_{2}$ concentrations on the $\mathrm{RF}$ is taken into account.

\section{B2 Tropospheric $\mathrm{O}_{3}$}

Atmospheric chemistry is simulated with CAM version 4 with MOZART chemistry (Emmons et al., 2010). In all cases CAM4 is set up with horizontal grid spacing of $1.9^{\circ}$ latitude by $2.5^{\circ}$ longitude with 26 vertical levels and a time step of $30 \mathrm{~min}$. Each simulation is branched from a 2-year spinup using year 2000 climate conditions (air temperature, sea surface temperature, solar forcing, etc.). Model setup is identical for all simulations except for trace gas emissions and $\mathrm{CH}_{4}$ concentrations, which are specific to the case (LULCC vs. no-LULCC, year 2010 vs. year 2100). In these simulations the tropospheric chemistry evolves differently depending on the initial emissions but does not interact with the model radiation. Therefore the CAM4 model climate is identical for all simulations and the RF of the changes in chemistry can be isolated. A 1-year post-spinup CAM4 integration is used for analysis of the RF.

To assess the global mean RF of $\mathrm{O}_{3}$ from the changes in emission of short-lived precursors and deposition, we compute radiative fluxes at the tropopause with the CAM4 output three-dimensional $\mathrm{O}_{3}$ fields included, and also with tropospheric $\mathrm{O}_{3}$ removed. This is accomplished by running the CAM4 radiation package offline with the Parallel Offline Radiative Transfer (PORT) tool (Conley et al., 2013). The difference in net radiative flux at the tropopause caused by removing $\mathrm{O}_{3}$ gives the total $\mathrm{RF}$ of tropospheric $\mathrm{O}_{3}$ in each case. The difference in $\mathrm{O}_{3}$ RF between cases with LULCC and the corresponding case without LULCC is equivalent to the contribution from LULCC to the RF. The contribution of other anthropogenic activities is estimated by computing the difference between the year 2010 or 2100 simulations without LULCC and the 1850 simulation without LULCC.

The short-lived $\mathrm{O}_{3} \mathrm{RF}$ estimated here is an instantaneous forcing since we do not allow for stratospheric temperature adjustment. Hansen et al. (2005) estimate a ratio of adjusted RF to instantaneous RF of approximately 0.8 in global simulations for the period between 1880 and 2000 . We multiply the instantaneous RFs for $\mathrm{O}_{3}$ by 0.8 to account for the stratospheric adjustment and report adjusted RFs.

Tropospheric $\mathrm{O}_{3}$ acts as a source for $\mathrm{OH}$. Therefore, changes to $\mathrm{O}_{3}$ concentrations lead to a response in $\mathrm{CH}_{4}$ and, as a consequence, a response in peroxy radical concentrations (Naik et al., 2005). The changes in peroxy radical concentrations, an end result of the changes in emissions of $\mathrm{O}_{3}$ precursors caused by LULCC or other anthropogenic activities, feed back onto $\mathrm{O}_{3}$, a response which is approximated with the following expression (Naik et al., 2005):

$\left(\Delta \mathrm{O}_{3}\right)_{\text {primary }}=\frac{\Delta\left[\mathrm{CH}_{4}\right]}{\left[\mathrm{CH}_{4}\right]} \cdot 6.4 \mathrm{DU}$.

We use a value of $0.032 \pm 0.006 \mathrm{~W} \mathrm{~m}^{-2} \mathrm{DU}^{-1}$ (Forster et al., 2007 ) to compute the additional $\mathrm{RF}$ of $\mathrm{O}_{3}$ caused by this process, known as the primary mode response.

\section{$\mathrm{B3} \mathrm{CH}_{4}$}

To compute direct (through emissions) and indirect (through altered chemical lifetime) changes in $\mathrm{CH}_{4}$ concentrations (due to LULCC and other anthropogenic activities), we treat them as separate perturbations to observed (year 2010) and projected (year 2100) concentrations. We compare the concentration with all anthropogenic $\mathrm{CH}_{4}$ sources/influences to the concentration with either LULCC or other anthropogenic sources/influences removed to compute the change in concentration for each case. The lifetime of $\mathrm{CH}_{4}$ in the atmosphere ( $\sim 9$ years) means our simulations are too short to directly simulate the changes in $\mathrm{CH}_{4}$ concentration. Instead we use approximations based on the known emissions of $\mathrm{CH}_{4}$ and changes in the quick-adjusting main chemical sink for $\mathrm{CH}_{4}$ - the hydroxyl radical $(\mathrm{OH})$.

If we remove direct emissions of $\mathrm{CH}_{4}$ from a particular source such as LULCC, a new steady-state concentration can be approximated using the following expression from Ward et al. (2012):

$\Delta\left[\mathrm{CH}_{4}\right]=F \cdot \frac{\Delta E}{E_{\mathrm{O}}} \cdot\left[\mathrm{CH}_{4}\right]_{\mathrm{O}}$,

such that a percentage change in $\mathrm{CH}_{4}$ emissions, $E$, leads to a percentage change in concentration, $\left[\mathrm{CH}_{4}\right]$, times the ratio of the perturbation lifetime to the initial lifetime, $F$. We do not calculate $F$ from our simulations but instead use $F=1.4$ as recommended by the IPCC (Prather et al., 2001).

Changes in global $\mathrm{OH}$ concentration can be used to approximate the change in $\mathrm{CH}_{4}$ lifetime caused by a change in emissions (Naik et al., 2005). Here we use the $\mathrm{OH}$ concentrations predicted in the CAM4 simulations for each case. The impact of non-LULCC emissions on $\mathrm{CH}_{4}$ lifetime is taken as the difference between the year 2010 or 2100 and year 1850 $\mathrm{CH}_{4}$ lifetime in the simulations with no LULCC emissions. Estimated this way, the $\mathrm{CH}_{4}$ lifetime decreases by more than 2 years between 1850 and 2010 and by 1.5 years between 1850 and 2100. 
We compute the change in concentration due to the change in $\mathrm{CH}_{4}$ lifetime, $\tau$, with respect to reaction with $\mathrm{OH}$ using this expression (Naik et al., 2005):

$\Delta\left[\mathrm{CH}_{4}\right]=F \cdot\left[\mathrm{CH}_{4}\right]_{\mathrm{O}} \cdot \frac{\Delta \tau}{\tau_{\mathrm{O}}}$.

Here we also use $F=1.4$ to account for the positive feedback between $\mathrm{CH}_{4}$ and $\mathrm{OH}$ (Naik et al., 2005).

The adjusted $\mathrm{RF}$ for the changes in $\mathrm{CH}_{4}$ concentration can be computed with the following expressions (Ramaswamy et al., 2001):

$$
\Delta F=0.036\left(\sqrt{M}-\sqrt{M_{\mathrm{O}}}\right)-\left[f\left(M, N_{\mathrm{O}}\right)-f\left(M_{\mathrm{O}}, N_{\mathrm{O}}\right)\right],
$$

$$
\begin{aligned}
f(M, N) & =0.47 \cdot \ln \left[1+2.01 \times 10^{-5}(M \cdot N)^{0.75}\right. \\
& \left.+5.31 \times 10^{-15} M(M \cdot N)^{1.52}\right]
\end{aligned}
$$

using the average tropospheric concentrations of $\mathrm{CH}_{4}(\mathrm{ppb})$ and $\mathrm{N}_{2} \mathrm{O}(\mathrm{ppb})$ in the perturbed state with LULCC or other anthropogenic emissions removed ( $M$ and $N$, respectively), and in the unperturbed, reference state $\left(M_{\mathrm{o}}\right.$ and $N_{\mathrm{o}}$, respectively).

\section{B4 $\mathrm{N}_{2} \mathrm{O}$ concentration}

Nitrous oxide is a long-lived greenhouse gas with a lifetime in the troposphere of over 100 years. Therefore, we use a simple atmospheric box model that can be run quickly for many model years to diagnose changes in $\mathrm{N}_{2} \mathrm{O}$ concentration that result from LULCC and other anthropogenic emissions. The box model uses an expression of $\mathrm{N}_{2} \mathrm{O}$ mass balance to predict changing concentrations, $C$, with time given yearly emissions, $E$, and a dynamic $\mathrm{N}_{2} \mathrm{O}$ lifetime, $\tau$ (Kroeze et al., 1999):

$$
\frac{\mathrm{d} C}{\mathrm{~d} t}=\frac{E}{S}-\frac{C}{\tau} .
$$

Here, $S$ is a conversion factor $\left(4.8 \mathrm{Tg} \mathrm{N}_{\mathrm{ppbv}}{ }^{-1}\right)$ and $t$ is time (years). The $\mathrm{N}_{2} \mathrm{O}$ lifetime is dependent on its own concentration, which we account for here following Meinshausen et al. (2011b) and using a year 2000 reference state:

$$
\tau=\tau_{\mathrm{O}}\left(\frac{C}{C_{\mathrm{O}}}\right)^{-0.05} \text {. }
$$

We run the box model from simulation year 1850 through 2100 with natural and anthropogenic emissions, but with emissions from the source of interest, either LULCC or other anthropogenic activities, removed. We assume that the decrease in natural $\mathrm{N}_{2} \mathrm{O}$ emissions (Syakila and Kroeze, 2011) is attributable to LULCC. This decreases the net LULCC emissions of $\mathrm{N}_{2} \mathrm{O}$.
The adjusted $\mathrm{RF}$ for the changes in $\mathrm{N}_{2} \mathrm{O}$ concentration can be computed with Eq. (B6) and the following expression from Ramaswamy et al. (2001):

$\Delta F=0.12\left(\sqrt{N}-\sqrt{N_{\mathrm{O}}}\right)-\left[f\left(M_{\mathrm{O}}, N\right)-f\left(M_{\mathrm{O}}, N_{\mathrm{O}}\right)\right]$,

using the average tropospheric concentrations of $\mathrm{CH}_{4}(\mathrm{ppb})$ and $\mathrm{N}_{2} \mathrm{O}(\mathrm{ppb})$ in the perturbed state with LULCC or other anthropogenic emissions removed ( $M$ and $N$, respectively), and in the unperturbed, reference state $\left(M_{\mathrm{o}}\right.$ and $N_{\mathrm{o}}$, respectively).

\section{B5 Aerosol effects}

CAM5 is used to simulate aerosol dynamics and the resulting radiative flux changes, as opposed to CAM4, to allow use of MAM3, which is not available for CAM4. Unfortunately chemistry was not yet available in CAM5 at the time of this study, and so different versions of the model had to be run for chemistry and aerosols. Since we use CAM4 and CAM5 to model concentration changes for separate forcing agents (trace gases in CAM4 and aerosols in CAM5), differences in physics between the two models do not affect our results. CAM5 is set up with horizontal grid spacing of $1.9^{\circ}$ latitude by $2.5^{\circ}$ longitude with 26 vertical levels and a time step of $30 \mathrm{~min}$. Each simulation is branched from a 2-year spinup using year 2000 climate conditions (air temperature, sea surface temperature, solar forcing, etc.). Model setup is identical for all simulations except for aerosol emissions, which are specific to the case (LULCC vs. no-LULCC, year 2010 vs. year 2100). In CAM5, aerosols are both radiatively and microphysically active. This enables simulation of aerosol indirect effects but leads to different model climates for different initial aerosol emissions. To isolate the impacts of aerosols on the RF we integrate CAM5 for 4 years post-spinup and use the annual average for analysis. This smooths out the interannual variability in the model climate state to minimize its impact on the RF (Wang et al., 2011).

Aerosols impact radiative transfer directly by scattering and absorbing shortwave and some longwave radiation, and also indirectly by their effects on clouds. We compute the direct effect of changes in aerosols from LULCC by running the CAM5 radiation online in a diagnostic mode separately from the prognostic radiation in the model. The radiation package is run at every time step through the model atmosphere with all aerosols and again with aerosols removed from interactions with radiation. The difference in top-ofatmosphere net radiative flux when aerosols are removed is the all-sky direct radiative effect. We compute this effect for shortwave and longwave interactions.

Indirect effects are defined here as the change in total cloud forcing between the simulations with and without LULCC (referenced to 1850), where total cloud forcing is the sum of the longwave and shortwave cloud forcing. This quantity is assessed after the direct effects of aerosols have been removed with the online diagnostics. Therefore, the 
sum of the direct effects and indirect effects of aerosols is equal to the total radiative change caused by aerosols in the CAM5 simulations.

In CAM5, the indirect effects of aerosols on clouds includes the first indirect effect by which aerosols, acting as cloud condensation nuclei, lead to changes in cloud droplet size and, as a consequence, cloud albedo. CAM5 also simulates aerosol-cloud interactions which are considered secondary indirect effects. These include aerosol impacts on stratiform cloud lifetime and height and the semidirect effect. The semidirect effect refers to the change in cloud fraction that results from the warming of an air layer by aerosol absorption of shortwave radiation (Lohmann and Feichter, 2005). Aerosol impacts on convective clouds are not included in our simulations.

These aspects of the CAM5 microphysics may lead to bias in our calculations when compared to the model consensus ERFs from the IPCC AR5 (Myhre et al., 2013). For this reason, and because models generally disagree on the magnitude of the aerosol effects (Forster et al., 2007), we use our results only to determine the proportion of the forcings from LULCC and non-LULCC, as explained in Sect. 2.4.

In addition to these effects in the atmosphere, lightabsorbing aerosols, particularly $\mathrm{BC}$ and dust, can decrease the albedo of the Earth's surface when they are deposited onto snow and ice surfaces. The Snow, Ice, and Aerosol Radiative (SNICAR) model (Flanner and Zender, 2006) is run online with CAM5 to simulate this process and estimate the RF. For all cases the RF of aerosol deposition onto snow and ice surfaces is between 0 and $0.03 \mathrm{~W} \mathrm{~m}^{-2}$. Note that we only capture aerosol deposition on snow and ice covering land and not over sea. This will reduce our estimates of the RF compared to estimates including sea ice, although the RF from aerosol deposition onto sea ice is thought to be less important than deposition onto land-covering snow and ice (Flanner et al., 2007).

\section{B6 Land surface albedo}

Albedo changes, apart from those caused by fires, are simulated by CLM (Sect. 2.4). For albedo changes from wildfire activity, post-fire albedo response curves (Ward et al., 2012) are applied to the difference in burned area with LULCC and without LULCC at each grid point. Fires lead to negative (cooling) RF from albedo changes on a global average (Ward et al., 2012). Since historical and projected LULCC reduced burned area in CLM, the result was a small but positive RF in all cases, acting in the opposite direction of the overall negative LULCC albedo change RF.

\section{B7 Biogeochemical and carbon-climate feedbacks}

The importance of aerosol biogeochemical feedbacks onto $\mathrm{CO}_{2}$ concentrations is beginning to be recognized and known impacts have recently been quantified (Mahowald, 2011). We consider changes to terrestrial uptake of carbon by the addition of $\mathrm{N}$ transported by aerosols, and also by modifications of climate.

$\mathrm{N}$ deposition from anthropogenic sources fertilizes vegetation growth and increases the drawdown of $\mathrm{CO}_{2}$, causing a present-day RF of -0.12 to $-0.35 \mathrm{~W} \mathrm{~m}^{-2}$. We multiply this forcing by the ratio of $\mathrm{N}$ emissions $\left(\mathrm{NH}_{3}, \mathrm{NO}_{\mathrm{x}}\right)$ from LULCC or other anthropogenic activities for each case to year 2010 total anthropogenic $\mathrm{N}$ emissions.

Changes in global surface temperature caused by the previously described RFs of LULCC and non-LULCC activities lead to a response in carbon uptake by the terrestrial biosphere and the ocean (Mahowald, 2011; Arneth et al., 2010). Moreover, aerosols affect vegetation by redistributing precipitation and changing the ratio of diffuse to direct radiation incident on the surface. While not very well understood, these biogeochemical feedbacks can be estimated by coupled carbon-climate models that suggest a roughly linear response of between 0 and $40 \mathrm{ppm} \mathrm{CO}_{2}$ for a $\mathrm{RF}$ of $1.4 \mathrm{~W} \mathrm{~m}^{-2}$ (Mahowald et al., 2011). We sum the total RF of LULCC for all cases from greenhouse gases, aerosol effects, and albedo changes in order to estimate the impact of the potential changes in climate on atmospheric $\mathrm{CO}_{2}$. In all cases, since the total RF from LULCC is positive, the RF of the feedback onto $\mathrm{CO}_{2}$ concentrations is also positive.

The total RFs of these biogeochemical feedbacks are included with the $\mathrm{CO}_{2} \mathrm{RF}$ in the tables and figures since they impact climate through changing $\mathrm{CO}_{2}$ concentrations.

\section{Appendix C: Computing uncertainties}

The uncertainties in RF estimations are substantial (Myhre et al., 2013) and include uncertainties in the model representation of physical and chemical processes, model internal variability, and imperfect knowledge of processes. Here we describe the calculation of uncertainties for the RFs reported in this paper and we assume the uncertainty has three sources: model and RF computations, partitioning of emissions between LULCC and non-LULCC, and uncertainty in the emissions from future fires (values given in Table $\mathrm{C} 1$ ).

\section{C1 Anthropogenic RF calculation uncertainties}

For the uncertainty in the total anthropogenic RF calculations, we take the $90 \%$ confidence intervals generated by the IPCC (Myrhe et al., 2013) for each forcing agent and assume these represent a Gaussian probability density function around the central estimate (Table C1, "Model" column). This assumption may not be appropriate for all forcing agents if the goal were to compute uncertainties that could be interpreted probabilistically. Therefore we stress that the calculated uncertainties are rough estimates and should not be interpreted as probabilistic. We propagate this uncertainty to LULCC and non-LULCC by multiplying by 
Table C1. Values for the three types of uncertainty calculated in this study. Uncertainty due to fires is specific to each future LULCC scenario and for other future anthropogenic activities (FF+).

\begin{tabular}{|c|c|c|c|c|c|c|c|c|}
\hline \multirow[b]{3}{*}{ Forcing } & \multirow{3}{*}{$\begin{array}{r}\text { Model } \\
{\left[\mathrm{W} \mathrm{m}^{-2}\right]}\end{array}$} & \multirow{3}{*}{$\begin{array}{r}\text { Partitioning } \\
{[\%]}\end{array}$} & \multicolumn{6}{|c|}{ Fire } \\
\hline & & & \multicolumn{6}{|c|}{$\left[\mathrm{W} \mathrm{m}^{-2}\right]$} \\
\hline & & & $\mathrm{RCP} 2.6$ & RCP4.5 & RCP6.0 & RCP8.5 & TEC $^{*}$ & $\mathrm{FF}+$ \\
\hline $\mathrm{CO}_{2}$ & \pm 0.12 & \pm 15 & \pm 0.04 & \pm 0.02 & \pm 0.04 & \pm 0.05 & \pm 0.15 & 0 \\
\hline $\mathrm{N}_{2} \mathrm{O}$ & \pm 0.01 & \pm 25 & 0 & 0 & 0 & 0 & 0 & 0 \\
\hline $\mathrm{CH}_{4}$ & \pm 0.03 & \pm 15 & \pm 0.01 & \pm 0.01 & \pm 0.01 & \pm 0.01 & \pm 0.02 & \pm 0.02 \\
\hline Ozone & \pm 0.12 & \pm 40 & 0 & 0 & 0 & 0 & \pm 0.01 & \pm 0.01 \\
\hline Aero DE & \pm 0.30 & \pm 40 & 0 & \pm 0.02 & \pm 0.02 & \pm 0.02 & \pm 0.1 & \pm 0.1 \\
\hline Aero IE & $+0.27,-0.46$ & \pm 40 & \pm 0.05 & \pm 0.02 & 0 & \pm 0.14 & \pm 0.23 & \pm 0.28 \\
\hline Albedo & \pm 0.06 & 0 & \pm 0.01 & \pm 0.01 & 0 & 0 & \pm 0.01 & 0 \\
\hline Ice alb. & $+0.03,-0.01$ & \pm 40 & 0 & \pm 0.01 & 0 & 0 & 0 & 0 \\
\hline Halocarbons & \pm 0.02 & 0 & 0 & 0 & 0 & 0 & 0 & 0 \\
\hline
\end{tabular}

* Theoretical extreme case.

the corresponding fraction of the RF from LULCC or nonLULCC, or, in the case of the aerosol forcings, by the fraction of AOD from LULCC or non-LULCC. Since we use the IPCC aerosol forcings in our total LULCC RF estimates, we do not include uncertainty introduced by the secondary aerosol effects.

\section{C2 Partitioning uncertainty}

The partitioning uncertainty is determined from previous estimates of the error in sector-specific trace gas and aerosol emissions. We define this uncertainty as the maximum range in the ratio of LULCC to non-LULCC emissions that could result from the two sources varying from plus to minus 1 standard deviation of their own source-specific uncertainty (Table C1, "Partitioning" column).

The source uncertainties for trace gases $\mathrm{CO}_{2}, \mathrm{CH}_{4}, \mathrm{NH}_{3}$, $\mathrm{NO}_{\mathrm{x}}$, and $\mathrm{N}_{2} \mathrm{O}$ are taken from the IPCC AR4 (Forster et al., 2007). The source uncertainties in emissions of $\mathrm{N}$ species (that is, the range in the ratio of LULCC $N$ emissions to nonLULCC $N$ emissions varying within the uncertainties from each source reported by Forster et al., 2007) are combined to produce the partitioning uncertainty of the aerosol biogeochemical feedback onto $\mathrm{CO}_{2}$ concentrations. The feedback of RF from non-LULCC and LULCC separately onto the carbon cycle (Sect. 2.4) is also included here as part of the $\mathrm{CO}_{2}$ partitioning uncertainty. The partitioning uncertainty for $\mathrm{CH}_{4}$ is combined with uncertainty in global sinks of $\mathrm{CH}_{4}$ (from Forster et al., 2007) that affect our understanding of the $\mathrm{CH}_{4}$ atmospheric lifetime. For emissions of $\mathrm{CO}$ (used in $\mathrm{O}_{3}$ partitioning uncertainty) we estimate a 2 -fold uncertainty in all emissions (Unger et al., 2010). Similarly, we begin with a 2-times uncertainty in aerosol emissions, as this has been estimated for carbonaceous aerosols (Unger et al., 2010), but, noting that the emissions of dust and SOA are more uncertain than emissions of carbonaceous aerosols, we double this uncertainty for aerosol emissions (4-times uncertainty). The partitioning uncertainties for halocarbon emissions and land surface albedo changes are zero since we only consider one source, LULCC or non-LULCC, for these forcing agents.

\section{C3 Summing the uncertainties}

Using the Monte Carlo method with $N=100000$ iterations, and assuming that the different forcing agents vary independently of one another, we produce Gaussian probability density functions for the combined RF (all agents, and LULCC and other anthropogenic sources) and for the LULCC RF (all agents, only LULCC sources). Adding these uncertainties together (root of the sum of squares) gives the uncertainty in the fraction of anthropogenic RF attributable to LULCC (Table 2). The assumption of independence among forcing agents is not perfect. For example, $\mathrm{NO}_{\mathrm{x}}$ concentrations are used to predict changes in $\mathrm{O}_{3}, \mathrm{CH}_{4}$, and total $\mathrm{N}$, and the same aerosol emissions are used to estimate several different forcings. However, given that there are large uncertainties specific to the calculation of each forcing agent, and apart from those associated with emissions, we retain the assumption of independence for approximating the sum of the uncertainties.

We apply the same uncertainties to the future RFs for LULCC and add additional uncertainty due to variability in global fire activity between 2010 and 2100 that is due to the different atmospheric forcing used in these simulations. We define this uncertainty as the total range in RF caused by using the different atmospheric forcing data sets to drive global fires in CLM (Table C1, "Fire" columns). The different forcing data sets were chosen to represent a large spread in projected temperature and precipitation by the year 2100 (Kloster et al., 2012). The uncertainties of the different forcing agents with regard to fire emissions are not independent of each other and are therefore added directly to the sum uncertainties after the Monte Carlo simulations have determined the sum of the other, more independent uncertainties. 
Acknowledgements. We would like to acknowledge the feedback and assistance of J. Kok, M. val Martin, J. Randerson, W. Woolford, and J. Lan, and referees T. Gasser and A. Arneth. We recognize funding from the National Science Foundation (NSF AGS-0758369, NSF-EaSM1049033, NSF-CI0832782) and the Guggenheim Foundation. Model integrations were performed with a National Center for Atmospheric Research facility, which is sponsored by the NSF.

Edited by: P. Chuang

\section{References}

Albani, S., Mahowald, N. M., Perry, A. T., Scanza, R. A., Zender, C. S., Heavens, N. G., Maggi, V., Kok, J. F., and Otto-Bliesner, B. L.: Improved dust representation in the Community Atmosphere Model, Journal of Advances in Modeling Earth Systems, 6, 1-30, doi:10.1002/2013MS000279, 2014.

Allen, M. R., Frame, D. J., Huntingford, C., Jones, C. D., Lowe, J. A., Meinshausen, M., and Meinshausen, N.: Warming caused by cumulative carbon emissions towards the trillionth tonne, Nature, 458, 1163-1166, 2009.

Arneth, A., Harrison, S. P., Zaehle, S., Tsigaridis, K., Menon, S., Bartlein, P. J., Feichter, J., Korhola, A., Kulmala, M., O'Donnell, D., Schurgers, G., Sorvari, S., and Vesala, T.: Terrestrial biogeochemical feedbacks in the climate system, Nat. Geosci., 3, 525532, doi:10.1038/ngeo905, 2010.

Arora, V. K. and Boer, G. J.: Uncertainties in the 20th century carbon budget associated with land use change, Global Change Biol., 16, 3327-3348, doi:10.1111/j.1365-2486.2010.02202.x, 2010.

Arora, V. K., Boer, G. J., Friedlingstein, P., Eby, M., Jones, C. D., Christian, J. R., Bonan, G., Bopp, L., Brovkin, V., Cadule, P., Hajima, T., Ilyina, T., Lindsay, K., Tjiputra, J. F., and Wu, T.: Carbon-Concentration and Carbon-Climate Feedbacks in CMIP5 Earth System Models, J. Climate, 26, 5289-5314, doi:10.1175/jcli-d-12-00494.1, 2013.

Ashworth, K., Wild, O., and Hewitt, C. N.: Sensitivity of isoprene emissions estimated using MEGAN to the time resolution of input climate data, Atmos. Chem. Phys., 10, 1193-1201, doi:10.5194/acp-10-1193-2010, 2010.

Bala, G., Caldeira, K., Wickett, M., Phillips, T. J., Lobell, D. B., Delire, C., and Mirin, A.: Combined climate and carbon-cycle effects of large-scale deforestation, P. Natl. Acad. Sci. USA, 104, 6550-6555, doi:10.1073/pnas.0608998104, 2007.

Batjes, N.: ISRIC-WISE global data set of derived soil properties on a 0.5 by 0.5 degree grid (Version 3.0), ISRIC-World Soil Inf. Rep, 8, the Netherlands, 24 pp., 2005.

Betts, R. A.: Biogeophysical impacts of land use on present-day climate: Near-surface temperature change and radiative forcing, Atmos. Sci. Lett., 2, 39-51, 2001.

Betts, R.: Comparing apples with oranges, Nature Reports Climate Change, 2, 7-8, doi:10.1038/climate.2007.74, 2008.

Betts, R. A., Falloon, P. D., Goldewijk, K. K., and Ramankutty, N.: Biogeophysical effects of land use on climate: Model simulations of radiative forcing and large-scale temperature change, Agr. Forest Meteorol., 142, 216-233, doi:10.1016/j.agrformet.2006.08.021, 2007.
Boucher, O., Myhre, G., and Myhre, A.: Direct human influence of irrigation on atmospheric water vapour and climate, Clim. Dynam., 22, 597-603, doi:10.1007/s00382-004-0402-4, 2004.

Brovkin, V., Sitch, S., von Bloh, W., Claussen, M., Bauer, E., and Cramer, W.: Role of land cover changes for atmospheric $\mathrm{CO}_{2}$ increase and climate change during the last 150 years, Global Change Biol., 10, 1253-1266, doi:10.1111/j.13652486.2004.00812.x, 2004.

Brovkin, V., Claussen, M., Driesschaert, E., Fichefet, T., Kicklighter, D., Loutre, M. F., Matthews, H. D., Ramankutty, N., Schaeffer, M., and Sokolov, A.: Biogeophysical effects of historical land cover changes simulated by six Earth system models of intermediate complexity, Clim. Dynam., 26, 587-600, doi:10.1007/s00382-005-0092-6, 2006.

Brovkin, V., Boysen, L., Arora, V. K., Boisier, J. P., Cadule, P., Chini, L., Claussen, M., Friedlingstein, P., Gayler, V., van den Hurk, B. J. J. M., Hurtt, G. C., Jones, C. D., Kato, E., de NobletDucoudré, N., Pacifico, F., Pongratz, J., and Weiss, M.: Effect of Anthropogenic Land-Use and Land-Cover Changes on Climate and Land Carbon Storage in CMIP5 Projections for the TwentyFirst Century, J. Climate, 26, 6859-6881, doi:10.1175/jcli-d-1200623.1, 2013.

Cherubini, F., Bright, R. M., and Strømman, A. H.: Site-specific global warming potentials of biogenic $\mathrm{CO}_{2}$ for bioenergy: contributions from carbon fluxes and albedo dynamics, Environ. Res. Lett., 7, 045902, doi:10.1088/1748-9326/7/4/045902, 2012.

Claussen, M., Brovkin, V., and Ganopolski, A.: Biogeophysical versus biogeochemical feedbacks of large-scale land cover change, Geophys. Res. Lett., 28, 1011-1014, doi:10.1029/2000gl012471, 2001.

Conley, A. J., Lamarque, J.-F., Vitt, F., Collins, W. D., and Kiehl, J.: PORT, a CESM tool for the diagnosis of radiative forcing, Geosci. Model Dev., 6, 469-476, doi:10.5194/gmd-6-469-2013, 2013.

Davin, E. L., de Noblet-Ducoudré, N., and Friedlingstein, P.: Impact of land cover change on surface climate: Relevance of the radiative forcing concept, Geophys. Res. Lett., 34, L13702, doi:10.1029/2007g1029678, 2007.

Defries, R. S., Bounoua, L., and Collatz, G. J.: Human modification of the landscape and surface climate in the next fifty years, Global Change Biol., 8, 438-458, doi:10.1046/j.13652486.2002.00483.x, 2002.

Di Vittorio, A. V., Chini, L. P., Bond-Lamberty, B., Mao, J., Shi, X., Truesdale, J., Craig, A., Calvin, K., Jones, A., Collins, W. D., Edmonds, J., Hurtt, G. C., Thornton, P., and Thomson, A.: From land use to land cover: restoring the afforestation signal in a coupled integrated assessment - earth system model and the implications for CMIP5 RCP simulations, Biogeosciences Discuss., 11, 7151-7188, doi:10.5194/bgd-11-7151-2014, 2014.

Eitelberg, D. A., van Vliet, J., and Verburg, P. H.: A review of global potentially available cropland estimates and their consequences for model-based assessments, Global Change Biol., preprint, doi:10.1111/gcb.12733, 2014.

Emmons, L. K., Walters, S., Hess, P. G., Lamarque, J.-F., Pfister, G. G., Fillmore, D., Granier, C., Guenther, A., Kinnison, D., Laepple, T., Orlando, J., Tie, X., Tyndall, G., Wiedinmyer, C., Baughcum, S. L., and Kloster, S.: Description and evaluation of the Model for Ozone and Related chemical Tracers, version 4 
(MOZART-4), Geosci. Model Dev., 3, 43-67, doi:10.5194/gmd3-43-2010, 2010.

Enting, I. G., Wigley, T., Heimann, M., and Scientific, C.: Future emissions and concentrations of carbon dioxide: Key ocean/atmosphere/land analyses, 31, CsIRO Australia, Australia, 133 pp., 1994.

FAO: Global Forest Resources Assessment 2010, Rome, 378 pp., 2010.

Feddema, J. J., Oleson, K. W., Bonan, G. B., Mearns, L. O., Buja, L. E., Meehl, G. A., and Washington, W. M.: The importance of land-cover change in simulating future climates, Science, 310, 1674-1678, doi:10.1126/science.1118160, 2005.

Flanner, M. G. and Zender, C. S.: Linking snowpack microphysics and albedo evolution, J. Geophys. Res.-Atmos., 111, D12208, doi:10.1029/2005JD006834, 2006.

Flanner, M. G., Zender, C. S., Randerson, J. T., and Rasch, P. J.: Present-day climate forcing and response from black carbon in snow, J. Geophys. Res.-Atmos., 112, D11202, doi:10.1029/2006JD008003, 2007.

Foley, J. A., Defries, R., Asner, G. P., Barford, C., Bonan, G., Carpenter, S. R., Chapin, F. S., Coe, M. T., Daily, G. C., Gibbs, H. K., Helkowski, J. H., Holloway, T., Howard, E. A., Kucharik, C. J., Monfreda, C., Patz, J. A., Prentice, I. C., Ramankutty, N., and Snyder, P. K.: Global consequences of land use, Science, 309, 570-574, doi:10.1126/science.1111772, 2005.

Foley, J. A., Ramankutty, N., Brauman, K. A., Cassidy, E. S., Gerber, J. S., Johnston, M., Mueller, N. D., O/'Connell, C., Ray, D. K., West, P. C., Balzer, C., Bennett, E. M., Carpenter, S. R., Hill, J., Monfreda, C., Polasky, S., Rockstrom, J., Sheehan, J., Siebert, S., Tilman, D., and Zaks, D. P. M.: Solutions for a cultivated planet, Nature, 478, 337-342, 2011.

Forster, P., Ramaswamy, V., Artaxo, P., Berntsen, T., Betts, R., Fahey, D. W., Haywood, J., Lean, J., Lowe, D. C., Myhre, G., Nganga, J., Prinn, R., Raga, G., Schulz, M., and Dorland, R. V.: Changes in Atmospheric Constituents and in Radiative Forcing, in: Climate Change 2007: The Physical Science Basis. Contribution of Working Group I to the Fourth Assessment Report of the Intergovernmental Panel on Climate Change, edited by: Solomon, S., Qin, D., Manning, M., Chen, Z., Marquis, M., Averyt, K. B., Tignor, M., and Miller, H. L., Cambridge University Press, New York City, NY, USA, 129-234, 2007.

Friedlingstein, P., Meinshausen, M., Arora, V. K., Jones, C. D., Anav, A., Liddicoat, S. K., and Knutti, R.: Uncertainties in CMIP5 Climate Projections due to Carbon Cycle Feedbacks, J. Climate, 27, 511-526, doi:10.1175/JCLI-D-12-00579.1, 2013.

Frolking, S., Talbot, J., Jones, M. C., Treat, C. C., Kauffman, J. B., Tuittila, E.-S., and Roulet, N.: Peatlands in the Earth's $21^{\text {st }}$ century climate system, Environ. Rev., 19, 371-396, doi:10.1139/A11-014, 2011.

Fujino, J., Nair, R., Kainuma, M., Masui, T., and Matsuoka, Y.: Multi-gas Mitigation Analysis on Stabilization Scenarios Using Aim Global Model, Energy Journal, 27, 343-353, 2006.

Ganzeveld, L., Bouwman, L., Stehfest, E., van Vuuren, D. P., Eickhout, B., and Lelieveld, J.: Impact of future land use and land cover changes on atmospheric chemistry-climate interactions, J. Geophys. Res., 115, D23301, doi:10.1029/2010jd014041, 2010.

Gent, P. R., Danabasoglu, G., Donner, L. J., Holland, M. M., Hunke, E. C., Jayne, S. R., Lawrence, D. M., Neale, R. B., Rasch, P. J., Vertenstein, M., Worley, P. H., Yang, Z.-L., and Zhang, M.: The
Community Climate System Model Version 4, J. Climate, 24, 4973-4991, doi:10.1175/2011JCLI4083.1, 2011.

Ginoux, P., Prospero, J. M., Gill, T. E., Hsu, N. C., and Zhao, M.: Global-scale attribution of anthropogenic and natural dust sources and their emission rates based on MODIS Deep Blue aerosol products, Rev. Geophys., 50, RG3005, doi:10.1029/2012RG000388, 2012.

Guenther, A., Karl, T., Harley, P., Wiedinmyer, C., Palmer, P. I., and Geron, C.: Estimates of global terrestrial isoprene emissions using MEGAN (Model of Emissions of Gases and Aerosols from Nature), Atmos. Chem. Phys., 6, 3181-3210, doi:10.5194/acp-63181-2006, 2006.

Guo, L. B. and Gifford, R.: Soil carbon stocks and land use change: a meta analysis, Global Change Biol., 8, 345-360, 2002.

Hansen, J., Sato, M., Ruedy, R., Nazarenko, L., Lacis, A., Schmidt, G. A., Russell, G., Aleinov, I., Bauer, M., Bauer, S., Bell, N., Cairns, B., Canuto, V., Chandler, M., Cheng, Y., Del Genio, A., Faluvegi, G., Fleming, E., Friend, A., Hall, T., Jackman, C., Kelley, M., Kiang, N., Koch, D., Lean, J., Lerner, J., Lo, K., Menon, S., Miller, R., Minnis, P., Novakov, T., Oinas, V., Perlwitz, J., Perlwitz, J., Rind, D., Romanou, A., Shindell, D., Stone, P., Sun, S., Tausnev, N., Thresher, D., Wielicki, B., Wong, T., Yao, M., and Zhang, S.: Efficacy of climate forcings, J. Geophys. Res.Atmos., 110, D18104, doi:10.1029/2005JD005776, 2005.

Hansen, M. C., Potapov, P. V., Moore, R., Hancher, M., Turubanova, S. A., Tyukavina, A., Thau, D., Stehman, S. V., Goetz, S. J., Loveland, T. R., Kommareddy, A., Egorov, A., Chini, L., Justice, C. O., and Townshend, J. R.: High-resolution global maps of 21st-century forest cover change, Science, 342, 850-853, doi:10.1126/science.1244693, 2013.

Harris, I., Jones, P. D., Osborn, T. J., and Lister, D. H.: Updated high-resolution grids of monthly climatic observations - the CRU TS3.10 Dataset, Int. J. Climatol., 34, 623-642, doi:10.1002/joc.3711, 2014.

Heald, C. L., Henze, D. K., Horowitz, L. W., Feddema, J., Lamarque, J. F., Guenther, A., Hess, P. G., Vitt, F., Seinfeld, J. H., Goldstein, A. H., and Fung, I.: Predicted change in global secondary organic aerosol concentrations in response to future climate, emissions, and land use change, J. Geophys. Res., 113, D05211, doi:10.1029/2007jd009092, 2008.

Hergoualc'h, K. and Verchot, L. V.: Stocks and fluxes of carbon associated with land use change in Southeast Asian tropical peatlands: A review, Global Biogeochem. Cy., 25, GB2001, doi:10.1029/2009gb003718, 2011.

Houghton, R. A.: How well do we know the flux of $\mathrm{CO}_{2}$ from land-use change?, Tellus B, 62, 337-351, doi:10.1111/j.16000889.2010.00473.x, 2010.

Houghton, R. A., Hobbie, J. E., Melillo, J. M., Moore, B., Peterson, B. J., Shaver, G. R., and Woodwell, G. M.: Changes in the carbon content of the terrestrial biota and soils between 1860 and 1980: A net release of $\mathrm{CO}_{2}$ to the atmosphere, Ecol. Monogr., 53, 235262, 1983.

House, J. I., Colin Prentice, I., and Le Quéré, C.: Maximum impacts of future reforestation or deforestation on atmospheric $\mathrm{CO}_{2}$, Global Change Biol., 8, 1047-1052, 2002.

Hurrell, J. W., Holland, M. M., Gent, P. R., Ghan, S., Kay, J. E., Kushner, P. J., Lamarque, J. F., Large, W. G., Lawrence, D., Lindsay, K., Lipscomb, W. H., Long, M. C., Mahowald, N., Marsh, D. R., Neale, R. B., Rasch, P., Vavrus, S., Vertenstein, 
M., Bader, D., Collins, W. D., Hack, J. J., Kiehl, J., and Marshall, S.: The Community Earth System Model: A Framework for Collaborative Research, B. Am. Meteorol. Soc., 94, 13391360, doi:10.1175/BAMS-D-12-00121.1, 2013.

Hurtt, G. C., Chini, L. P., Frolking, S., Betts, R. A., Feddema, J., Fischer, G., Fisk, J. P., Hibbard, K., Houghton, R. A., Janetos, A., Jones, C. D., Kindermann, G., Kinoshita, T., Klein Goldewijk, K., Riahi, K., Shevliakova, E., Smith, S., Stehfest, E., Thomson, A., Thornton, P., Vuuren, D. P., and Wang, Y. P.: Harmonization of land-use scenarios for the period 1500-2100: 600 years of global gridded annual land-use transitions, wood harvest, and resulting secondary lands, Climatic Change, 109, 117-161, doi:10.1007/s10584-011-0153-2, 2011.

Jones, A. D., Collins, W. D., and Torn, M. S.: On the additivity of radiative forcing between land use change and greenhouse gases, Geophys. Res. Lett., 40, 4036-4041, doi:10.1002/grl.50754, 2013.

Jones, C., Robertson, E., Arora, V., Friedlingstein, P., Shevliakova, E., Bopp, L., Brovkin, V., Hajima, T., Kato, E., Kawamiya, M., Liddicoat, S., Lindsay, K., Reick, C. H., Roelandt, C., Segschneider, J., and Tjiputra, J.: Twenty-First-Century Compatible $\mathrm{CO}_{2}$ Emissions and Airborne Fraction Simulated by CMIP5 Earth System Models under Four Representative Concentration Pathways, J. Climate, 26, 4398-4413, doi:10.1175/jcli-d-12-00554.1, 2013.

Kloster, S., Mahowald, N. M., Randerson, J. T., Thornton, P. E., Hoffman, F. M., Levis, S., Lawrence, P. J., Feddema, J. J., Oleson, K. W., and Lawrence, D. M.: Fire dynamics during the 20th century simulated by the Community Land Model, Biogeosciences, 7, 1877-1902, doi:10.5194/bg-7-1877-2010, 2010.

Kloster, S., Mahowald, N. M., Randerson, J. T., and Lawrence, P. J.: The impacts of climate, land use, and demography on fires during the 21 st century simulated by CLM-CN, Biogeosciences, 9, 509-525, doi:10.5194/bg-9-509-2012, 2012.

Kroeze, C., Mosier, A., and Bouwman, L.: Closing the global $\mathrm{N}_{2} \mathrm{O}$ budget: A retrospective analysis 1500-1994, Global Biogeochem. Cy., 13, 1-8, 1999.

Lal, R.: Soil carbon sequestration impacts on global climate change and food security, Science, 304, 1623-1627, doi:10.1126/science.1097396, 2004.

Lamarque, J. F., Kiehl, J. T., Brasseur, G. P., Butler, T., CameronSmith, P., Collins, W. D., Collins, W. J., Granier, C., Hauglustaine, D., Hess, P. G., Holland, E. A., Horowitz, L., Lawrence, M. G., McKenna, D., Merilees, P., Prather, M. J., Rasch, P. J., Rotman, D., Shindell, D., and Thornton, P.: Assessing future nitrogen deposition and carbon cycle feedback using a multimodel approach: Analysis of nitrogen deposition, J. Geophys. Res.-Atmos., 110, D19303, doi:10.1029/2005JD005825, 2005.

Lamarque, J.-F., Bond, T. C., Eyring, V., Granier, C., Heil, A., Klimont, Z., Lee, D., Liousse, C., Mieville, A., Owen, B., Schultz, M. G., Shindell, D., Smith, S. J., Stehfest, E., Van Aardenne, J., Cooper, O. R., Kainuma, M., Mahowald, N., McConnell, J. R., Naik, V., Riahi, K., and van Vuuren, D. P.: Historical (1850-2000) gridded anthropogenic and biomass burning emissions of reactive gases and aerosols: methodology and application, Atmos. Chem. Phys., 10, 7017-7039, doi:10.5194/acp10-7017-2010, 2010.

Lawrence, P. J. and Chase, T. N.: Investigating the climate impacts of global land cover change in the community climate system model, Int. J. Climatol., 30, 2066-2087, doi:10.1002/joc.2061, 2010.

Lawrence, P. J., Feddema, J. J., Bonan, G. B., Meehl, G. A., O’Neill, B. C., Oleson, K. W., Levis, S., Lawrence, D. M., Kluzek, E., Lindsay, K., and Thornton, P. E.: Simulating the Biogeochemical and Biogeophysical Impacts of Transient Land Cover Change and Wood Harvest in the Community Climate System Model (CCSM4) from 1850 to 2100, J. Climate, 25, 3071-3095, doi:10.1175/jcli-d-11-00256.1, 2012.

Lehner, B. and Doll, P.: Development and validation of a global database of lakes resevoirs and wetlands, J. Hydrol., 296, 1-22, 2004.

Levis, S., Hartman, M. D., and Bonan, G. B.: The Community Land Model underestimates land-use $\mathrm{CO}_{2}$ emissions by neglecting soil disturbance from cultivation, Geosci. Model Dev., 7, 613-620, doi:10.5194/gmd-7-613-2014, 2014.

Liu, X., Xie, S., Boyle, J., Klein, S. A., Shi, X., Wang, Z., Lin, W., Ghan, S. J., Earle, M., Liu, P. S. K., and Zelenyuk, A.: Testing cloud microphysics parameterizations in NCAR CAM5 with ISDAC and M-PACE observations, J. Geophys. Res.-Atmos., 116, D00T11, doi:10.1029/2011JD015889, 2011.

Liu, X., Easter, R. C., Ghan, S. J., Zaveri, R., Rasch, P., Shi, X., Lamarque, J.-F., Gettelman, A., Morrison, H., Vitt, F., Conley, A., Park, S., Neale, R., Hannay, C., Ekman, A. M. L., Hess, P., Mahowald, N., Collins, W., Iacono, M. J., Bretherton, C. S., Flanner, M. G., and Mitchell, D.: Toward a minimal representation of aerosols in climate models: description and evaluation in the Community Atmosphere Model CAM5, Geosci. Model Dev., 5, 709-739, doi:10.5194/gmd-5-709-2012, 2012.

Lohmann, U. and Feichter, J.: Global indirect aerosol effects: a review, Atmos. Chem. Phys., 5, 715-737, doi:10.5194/acp-5-7152005, 2005.

Mahowald, N.: Aerosol indirect effect on biogeochemical cycles and climate, Science, 334, 794-796, doi:10.1126/science.1207374, 2011.

Mahowald, N. M., Muhs, D. R., Levis, S., Rasch, P. J., Yoshioka, M., Zender, C. S., and Luo, C.: Change in atmospheric mineral aerosols in response to climate: Last glacial period, preindustrial, modern, and doubled carbon dioxide climates, J. Geophys. Res., 111, D10202, doi:10.1029/2005jd006653, 2006.

Mahowald, N., Ward, D. S., Kloster, S., Flanner, M. G., Heald, C. L., Heavens, N. G., Hess, P. G., Lamarque, J.-F., and Chuang, P. Y.: Aerosol Impacts on Climate and Biogeochemistry, Annu. Rev. Env. Resour., 36, 45-74, doi:10.1146/annurev-environ042009-094507, 2011.

Marlon, J. R., Bartlein, P. J., Carcaillet, C., Gavin, D. G., Harrison, S. P., Higuera, P. E., Joos, F., Power, M. J., and Prentice, I. C.: Climate and human influences on global biomass burning over the past two millennia, Nat. Geosci., 1, 697-702, doi:10.1038/ngeo313, 2008.

Matthews, H. D., Weaver, A. J., Meissner, K. J., Gillett, N. P., and Eby, M.: Natural and anthropogenic climate change: incorporating historical land cover change, vegetation dynamics and the global carbon cycle, Clim. Dynam., 22, 461-479, doi:10.1007/s00382-004-0392-2, 2004.

Meinshausen, M., Meinshausen, N., Hare, W., Raper, S. C., Frieler, K., Knutti, R., Frame, D. J., and Allen, M. R.: Greenhouse-gas emission targets for limiting global warming to $2^{\circ} \mathrm{C}$, Nature, 458, 1158-1162, doi:10.1038/nature08017, 2009. 
Meinshausen, M., Raper, S. C. B., and Wigley, T. M. L.: Emulating coupled atmosphere-ocean and carbon cycle models with a simpler model, MAGICC6 - Part 1: Model description and calibration, Atmos. Chem. Phys., 11, 1417-1456, doi:10.5194/acp11-1417-2011, 2011 a.

Meinshausen, M., Smith, S. J., Calvin, K., Daniel, J. S., Kainuma, M. L. T., Lamarque, J. F., Matsumoto, K., Montzka, S. A., Raper, S. C. B., Riahi, K., Thomson, A., Velders, G. J. M., and Vuuren, D. P. P.: The RCP greenhouse gas concentrations and their extensions from 1765 to 2300, Climatic Change, 109, 213-241, doi:10.1007/s10584-011-0156-z, 2011b.

Meyfroidt, P. and Lambin, E. F.: Global Forest Transition: Prospects for an End to Deforestation, Ann. Rev. Env. Resour., 36, $343-$ 371, doi:10.1146/annurev-environ-090710-143732, 2011.

Morrison, H. and Gettelman, A.: A New Two-Moment Bulk Stratiform Cloud Microphysics Scheme in the Community Atmosphere Model, Version 3 (CAM3). Part I: Description and Numerical Tests, J. Climate, 21, 3642-3659, doi:10.1175/2008JCLI2105.1, 2008.

Moss, R. H., Edmonds, J. A., Hibbard, K. A., Manning, M. R., Rose, S. K., van Vuuren, D. P., Carter, T. R., Emori, S., Kainuma, M., Kram, T., Meehl, G. A., Mitchell, J. F., Nakicenovic, N., Riahi, K., Smith, S. J., Stouffer, R. J., Thomson, A. M., Weyant, J. P., and Wilbanks, T. J.: The next generation of scenarios for climate change research and assessment, Nature, 463, 747-756, doi:10.1038/nature08823, 2010.

Myhre, G., Shindell, D., Breon, F.-M., Collins, W., Fuglestvedt, J., Huang, J., Koch, D., Lamarque, J. F., Lee, D., Mendoza, B., Nakajima, T., Robock, A., Stephens, G., Takemura, T., and Zhang, H.: Anthropogenic and Natural Radiative Forcing, in: Climate Change 2013: The Physical Science Basis. Contribution of Working Group I to the Fifth Assessment Report of the Intergovernmental Panel on Climate Change, edited by: Stocker, T. F., Qin, D., Plattner, G.-K., Tignor, M., Allen, S. K., Boschung, J., Nauels, A., Xia, Y.,Bex, V., and Midgley, P. M., Cambridge University Press, New York, NY, USA, 659-740, 2013.

Naik, V., Mauzerall, D., Horowitz, L., Schwarzkopf, M. D., Ramaswamy, V., and Oppenheimer, M.: Net radiative forcing due to changes in regional emissions of tropospheric ozone precursors, J. Geophys. Res., 110, D24306, doi:10.1029/2005jd005908, 2005.

O’Halloran, T. L., Law, B. E., Goulden, M. L., Wang, Z., Barr, J. G., Schaaf, C., Brown, M., Fuentes, J. D., Göckede, M., Black, A., and Engel, V.: Radiative forcing of natural forest disturbances, Global Change Biol., 18, 555-565, doi:10.1111/j.13652486.2011.02577.x, 2011.

Oleson, K. W., Niu, G. Y., Yang, Z. L., Lawrence, D. M., Thornton, P. E., Lawrence, P. J., Stöckli, R., Dickinson, R. E., Bonan, G. B., Levis, S., Dai, A., and Qian, T.: Improvements to the Community Land Model and their impact on the hydrological cycle, J. Geophys. Res., 113, G01021, doi:10.1029/2007jg000563, 2008.

Pielke, R. A., Marland, G., Betts, R. A., Chase, T. N., Eastman, J. L., Niles, J. O., Niyogi, D. S., and Running, S. W.: The influence of land-use change and landscape dynamics on the climate system: relevance to climate-change policy beyond the radiative effect of greenhouse gases, Philisophical Transactions of the Royal Society A, 360, 1705-1719, 2002.

Pitman, A. J., de Noblet-Ducoudré, N., Cruz, F. T., Davin, E. L., Bonan, G. B., Brovkin, V., Claussen, M., Delire, C., Ganzeveld,
L., Gayler, V., van den Hurk, B. J. J. M., Lawrence, P. J., van der Molen, M. K., Müller, C., Reick, C. H., Seneviratne, S. I., Strengers, B. J., and Voldoire, A.: Uncertainties in climate responses to past land cover change: First results from the LUCID intercomparison study, Geophys. Res. Lett., 36, L14814, doi:10.1029/2009g1039076, 2009.

Pongratz, J. and Caldiera, K.: Attribution of atmospheric $\mathrm{CO}_{2}$ and temperature increases to regions: importance of preindustrial land use change, Environ. Res. Lett., 7, 034001, 8 pp., doi:10.1088/1748-9326/7/3/034001, 2012.

Pongratz, J., Reick, C., Raddatz, T., and Claussen, M.: A reconstruction of global agricultural areas and land cover for the last millennium, Global Biogeochem. Cy., 22, GB3018, doi:10.1029/2007gb003153, 2008.

Pongratz, J., Raddatz, T., Reick, C. H., Esch, M., and Claussen, M.: Radiative forcing from anthropogenic land cover change since A.D. 800, Geophys. Res. Lett., 36, L02709, doi:10.1029/2008g1036394, 2009.

Pongratz, J., Reick, C. H., Houghton, R. A., and House, J. I.: Terminology as a key uncertainty in net land use and land cover change carbon flux estimates, Earth Syst. Dynam., 5, 177-195, doi:10.5194/esd-5-177-2014, 2014.

Prather, M., Ehhalt, D., Dentener, F., Derwent, R., Dlugokencky, E. J., Holland, E., Isaksen, I., Katima, J., Kirchhoff, V., Matson, P., Midgley, P., and Wang, M.: Atmospheric Chemistry and Greenhouse Gases, in: Climate Change 2001: The Scientific Basis, edited by: Houghton, J. T., Ding, Y., Griggs, D. J., Noguer, M., Van der Linden, P. J., Dai, X., Maskell, K., and Johnson, C. A., Intergovernmental Panel on Climate Change, Cambridge University Press, Cambridge, 239-287, 2001.

Ramankutty, N., Foley, J. A., Norman, J., and McSweeney, K.: The global distribution of cultivable lands: current patterns and sensitivity to possible climate change, Global Ecol. Biogeogr., 11, 377-392, doi:10.1046/j.1466-822x.2002.00294.x, 2002.

Ramankutty, N., Evan, A. T., Monfreda, C., and Foley, J. A.: Farming the planet: 1 . Geographic distribution of global agricultural lands in the year 2000, Global Biogeochem. Cy., 22, GB1003, doi:10.1029/2007GB002952, 2008.

Ramaswamy, V., Boucher, O., Haigh, J., Hauglustine, D., Haywood, J., Myhre, G., Nakajima, T., Shi, G., and Solomon, S.: Radiative forcing of climate, in: Climate Change 2001: The Scientific Basis, edited by: Houghton, J. T., Ding, Y., Griggs, D. J., Noguer, M., Van der Linden, P. J., Dai, X., Maskell, K., and Johnson, C. A., Intergovernmental Panel on Climate Change, Cambridge University Press, Cambridge, UK, 349-416, 2001.

Randerson, J. T., Liu, H., Flanner, M. G., Chambers, S. D., Jin, Y., Hess, P. G., Pfister, G., Mack, M. C., Treseder, K. K., Welp, L. R., Chapin, F. S., Harden, J. W., Goulden, M. L., Lyons, E., Neff, J. C., Schuur, E. A., and Zender, C. S.: The impact of boreal forest fire on climate warming, Science, 314, 1130-1132, doi:10.1126/science.1132075, 2006.

Reay, D. S., Davidson, E. A., Smith, K. A., Smith, P., Melillo, J. M., Dentener, F., and Crutzen, P. J.: Global agriculture and nitrous oxide emissions, Nature Climate Change, 2, 410-416, 2012.

Riahi, K., Grübler, A., and Nakicenovic, N.: Scenarios of longterm socio-economic and environmental development under climate stabilization, Technol. Forecast. Soc., 74, 887-935, doi:10.1016/j.techfore.2006.05.026, 2007. 
Rulli, M. C., Saviori, A., and D'Odorico, P.: Global land and water grabbing, P. Natl. Acad. Sci. USA, 110, 892-897, doi:10.1073/pnas.1213163110, 2013.

Runyan, C. W., D’Odorico, P., and Lawrence, D.: Physical and biological feedbacks of deforestation, Rev. Geophys., 50, RG4006, doi:10.1029/2012rg000394, 2012.

Shevliakova, E., Pacala, S. W., Malyshev, S., Hurtt, G. C., Milly, P. C. D., Caspersen, J. P., Sentman, L. T., Fisk, J. P., Wirth, C., and Crevoisier, C.: Carbon cycling under 300 years of land use change: Importance of the secondary vegetation sink, Global Biogeochem. Cy., 23, GB2022, doi:10.1029/2007gb003176, 2009.

Shindell, D. T., Faluvegi, G., Koch, D. M., Schmidt, G. A., Unger, N., and Bauer, S. E.: Improved attribution of climate forcing to emissions, Science, 326, 716-718, doi:10.1126/science.1174760, 2009.

Shine, K. P., Berntsen, T. K., Fuglestvedt, J. S., Skeie, R. B., and Stuber, N.: Comparing the climate effect of emissions of shortand long-lived climate agents, Philosophical transactions. Series A, Mathematical, physical, and engineering sciences, 365, 19031914, doi:10.1098/rsta.2007.2050, 2007.

Sitch, S., Brovkin, V., von Bloh, W., van Vuuren, D., Eickhout, B., and Ganopolski, A.: Impacts of future land cover changes on atmospheric $\mathrm{CO}_{2}$ and climate, Global Biogeochem. Cy., 19, GB2013, doi:10.1029/2004gb002311, 2005.

Skeie, R. B., Berntsen, T. K., Myhre, G., Tanaka, K., Kvalevåg, M. M., and Hoyle, C. R.: Anthropogenic radiative forcing time series from pre-industrial times until 2010, Atmos. Chem. Phys., 11, 11827-11857, doi:10.5194/acp-11-11827-2011, 2011.

Sterling, S. M., Ducharne, A., and Polcher, J.: The impact of global land-cover change on the terrestrial water cycle, Nat. Clim. Change, 3, 385-390, 2013.

Stöckli, R., Lawrence, D. M., Niu, G. Y., Oleson, K. W., Thornton, P. E., Yang, Z. L., Bonan, G. B., Denning, A. S., and Running, S. W.: Use of FLUXNET in the Community Land Model development, J. Geophys. Res.-Biogeo., 113, G01025, doi:10.1029/2007JG000562, 2008.

Strassmann, K. M., Joos, F., and Fischer, G.: Simulating effects of land use changes on carbon fluxes: past contributions to atmospheric $\mathrm{CO}_{2}$ increases and future commitments due to losses of terrestrial sink capacity, Tellus B, 60, 583-603, doi:10.1111/j.1600-0889.2008.00340.x, 2008.

Strengers, B. J., Müller, C., Schaeffer, M., Haarsma, R. J., Severijns, C., Gerten, D., Schaphoff, S., van den Houdt, R., and Oostenrijk, R.: Assessing 20th century climate-vegetation feedbacks of land-use change and natural vegetation dynamics in a fully coupled vegetation-climate model, Int. J. Climatol., 30, 2055-2065, doi:10.1002/joc.2132, 2010.

Syakila, A. and Kroeze, C.: The global nitrous oxide budget revisited, Greenhouse Gas Measurement and Management, 1, 17-26, doi:10.3763/ghgmm.2010.0007, 2011.
Taylor, K. E., Stouffer, R. J., and Meehl, G. A.: An Overview of CMIP5 and the Experiment Design, B. Am. Meteorol. Soc., 93, 485-498, doi:10.1175/bams-d-11-00094.1, 2012.

Thornton, P. E., Doney, S. C., Lindsay, K., Moore, J. K., Mahowald, N., Randerson, J. T., Fung, I., Lamarque, J.-F., Feddema, J. J., and Lee, Y.-H.: Carbon-nitrogen interactions regulate climate-carbon cycle feedbacks: results from an atmosphereocean general circulation model, Biogeosciences, 6, 2099-2120, doi:10.5194/bg-6-2099-2009, 2009.

Tubiello, F. N., Salvatore, M., Rossi, S., Ferrara, A., Fitton, N., and Smith, P.: The FAOSTAT database of greenhouse gas emissions from agriculture, Environ. Res. Lett., 8, 015009, doi:10.1088/1748-9326/8/1/015009, 2013.

Unger, N., Bond, T. C., Wang, J. S., Koch, D. M., Menon, S., Shindell, D. T., and Bauer, S.: Attribution of climate forcing to economic sectors, P. Natl. Acad. Sci. USA, of the United States of America, 107, 3382-3387, doi:10.1073/pnas.0906548107, 2010. van Vuuren, D. P., Edmonds, J., Kainuma, M., Riahi, K., Thomson, A., Hibbard, K., Hurtt, G. C., Kram, T., Krey, V., Lamarque, J.F., Masui, T., Meinshausen, M., Nakicenovic, N., Smith, S. J., and Rose, S. K.: The representative concentration pathways: an overview, Climatic Change, 109, 5-31, doi:10.1007/s10584-0110148-z, 2011.

van Vuuren, D. P., Elzen, M. G. J., Lucas, P. L., Eickhout, B., Strengers, B. J., Ruijven, B., Wonink, S., and Houdt, R.: Stabilizing greenhouse gas concentrations at low levels: an assessment of reduction strategies and costs, Climatic Change, 81, 119-159, doi:10.1007/s10584-006-9172-9, 2007.

Wang, M., Ghan, S., Ovchinnikov, M., Liu, X., Easter, R., Kassianov, E., Qian, Y., and Morrison, H.: Aerosol indirect effects in a multi-scale aerosol-climate model PNNL-MMF, Atmos. Chem. Phys., 11, 5431-5455, doi:10.5194/acp-11-5431-2011, 2011.

Ward, D. S., Kloster, S., Mahowald, N. M., Rogers, B. M., Randerson, J. T., and Hess, P. G.: The changing radiative forcing of fires: global model estimates for past, present and future, Atmos. Chem. Phys., 12, 10857-10886, doi:10.5194/acp12-10857-2012, 2012.

Willmott, C. J. and Feddema, J. J.: A more rational climatic moisture index*, The Professional Geographer, 44, 84-88, 1992.

Wise, M., Calvin, K., Thomson, A., Clarke, L., Bond-Lamberty, B., Sands, R., Smith, S. J., Janetos, A., and Edmonds, J.: Implications of limiting $\mathrm{CO}_{2}$ concentrations for land use and energy, Science, 324, 1183-1186, doi:10.1126/science.1168475, 2009.

Wu, S., Mickley, L. J., Kaplan, J. O., and Jacob, D. J.: Impacts of changes in land use and land cover on atmospheric chemistry and air quality over the 21st century, Atmos. Chem. Phys., 12, 15971609, doi:10.5194/acp-12-1597-2012, 2012.

Zaehle, S., Ciais, P., Friend, A. D., and Prieur, V.: Carbon benefits of anthropogenic reactive nitrogen offset by nitrous oxide emissions, Nature Geosci., 4, 601-605, 2011. 